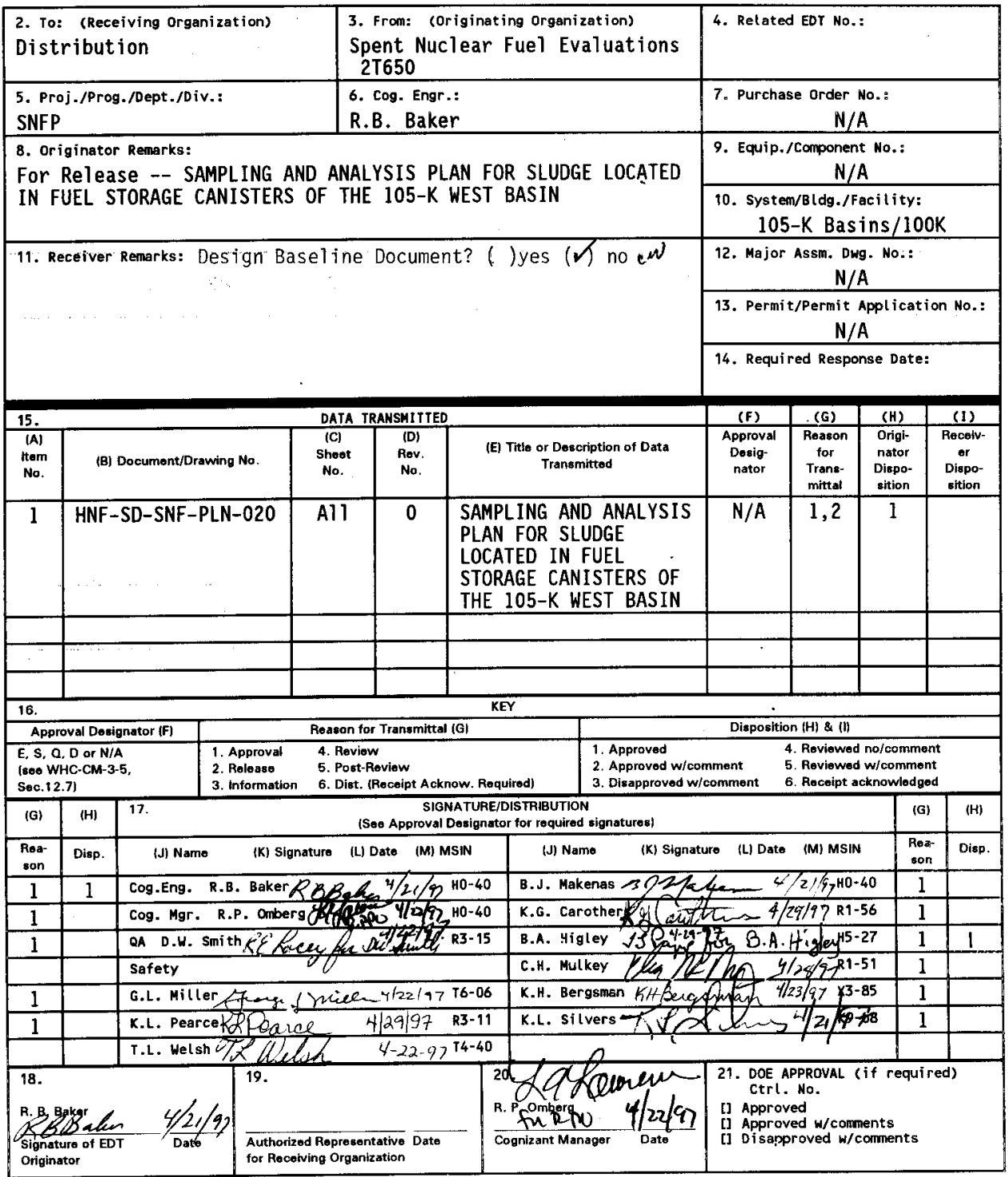




\section{SAMPLING AND ANALYSIS PLAN FOR SLUDGE LOCATED IN FUEL STORAGE CANISTERS OF THE 105-K WEST BASIN}

T. L. Welsh, R. B. Baker, B. J. Makenas, and K. L. Pearce

Duke Engineering \& Services Hanford, Inc., Richland, WA 99352

U.S. Department of Energy Contract DE-AC06-96RL13200

EDT/ECN: $620779 \quad$ UC: 2070

Org Code: 2T650 Charge Code: LB032

B\&R Code: EW 3135040 Total Pages: $4547 \mathrm{cW}$

Key Words: K Basins, K West Basin, Sampling and Analys is Plan, Sludge Characterization, Spent Nuclear Fuel Project, and Spent Fuel Canisters

Abstract: This Sampling and Analysis Plan (SAP) provides direction for the first sampling of sludge from the $K$ West Basin spent fuel canisters. The specially developed sampling equipment removes representative samples of sludge while maintaining the radioactive sample underwater in the basin pool (equipment is described in WHC-SD-SNF-SDD-004). Included are the basic background logic for sample selection, the overall laboratory analyses required and the laboratory reporting required. These are based on requirements put forth in the data quality objectives (WHC-SD-SNF-DQ0-012) established for this sampling and characterization activity.

TRADEMARK DISCLAIMER. Reference herein to any specific commercial product, process, or service by trade nane, trademark, manufacturer, or otherwise, does not necessarily constitute or imply its endorsement, recommendation, or favoring by the United States Government or any agency thereof or its contractors or subcontractors.

Printed in the United States of America. To obtain copies of this document, contact: Document Control Services, P.0. Box 950, Mailstop H6-08, Richland WA 99352, Phone (50́9) 372-2420: Fax (509) 376-4989.
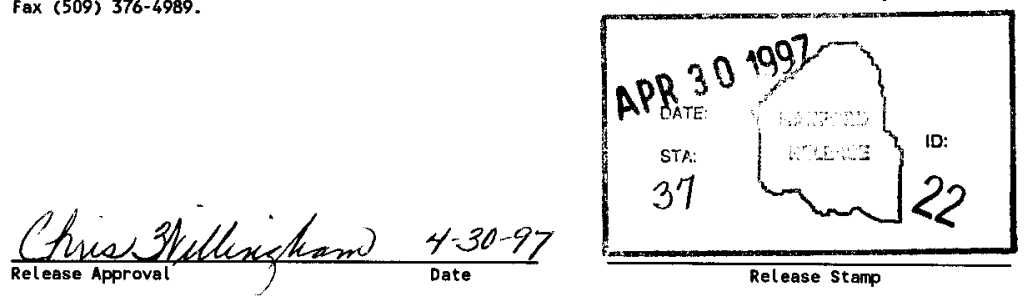
HNF-SD-SNF-PLN-020, Rev. 0

\section{SAMPLING AND ANALYSIS PLAN FOR SLUDGE LOCATED IN FUEL} STORAGE CANISTERS OF THE 105-K WEST BASIN

T. L. Welsh, R. B. Baker, B. J. Makenas, and K. L. Pearce Apri1 1997 


\section{CONTENTS}

1.0 SAMPLING OBJECTIVES $\ldots \ldots \ldots \ldots$

1.1 PURPOSE . . . . . . . . . . . . . 5

1.2 SAMPLING AND ANALYSIS ACTIVITY OBJECTIVE AND GOALS $\ldots . . .66$

$2.0 \quad 105-K$ EAST BASIN STATUS AND SAMPLING INFORMATION . . . . . . 11

$2.1 \quad 105-K$ WEST BASIN STATUS . . . . . . . . . . . . . 11

$2.2105-K$ EAST BASIN SLUDGE CHARACTERIZATION STATUS $\ldots \ldots \ldots . . .12$

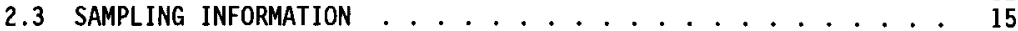

2.3.1 Sample Collection and Handling ............ 15

2.3.2 Sample Record Keeping . . . . . . . . . . . . 17

2.3.3 Field Sample Plan Modifications ........... 18

2.3.4 Sampling Locations............... 18

2.3.5 Sample Preparation . . . . . . . . . . . . 19

3.0 LABORATORY ANALYSIS INSTRUCTIONS ............... 21

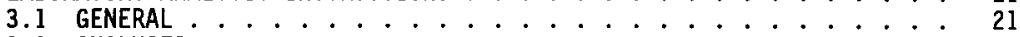

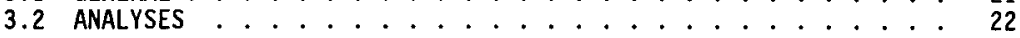

4.0 LABORATORY REPORTING REQUIREMENTS . . . . . . . . . . . 33

4.1 DATA PACKAGING .................... 33

5.0 FINAL SUMMARY REPORT REQUIREMENTS . . . . . . . . . . . . . . 35

5.1 STATISTICAL ANALYSIS REQUIREMENTS ............. 35

6.0 SAFETY PLANS . . . . . . . . . . . . . . . . . . . . . 37

6.1 RADIATION/INDUSTRIAL SAFETY . . . . . . . . . . 37

6.2 NUCLEAR CRITICALITY SAFETY $\ldots \ldots \ldots . \ldots . \ldots . \ldots$

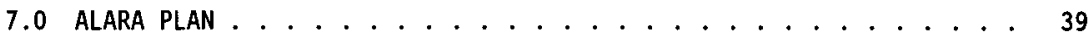

8.0 QUALITY ASSURANCE AND CONTROL PLAN ............. 41

9.0 REFERENCES ....................... . . 43 
HNF-SD-SNF-PLN-020, Rev. 0

\section{LIST OF FIGURES}

1. Overview of Canister Sludge Sampling Equipment . . . . . . . . 16

2. General Sample Analysis Strategy ............... 23

\section{LIST OF TABLES}

1. 105-K West Canister Sludge Analyses for the Analytical Laboratory ................. . 24

2. Analytical Requirements for the $105-K$ West Basin Canister Sludge Samples................. 26 


\section{LIST OF TERMS}

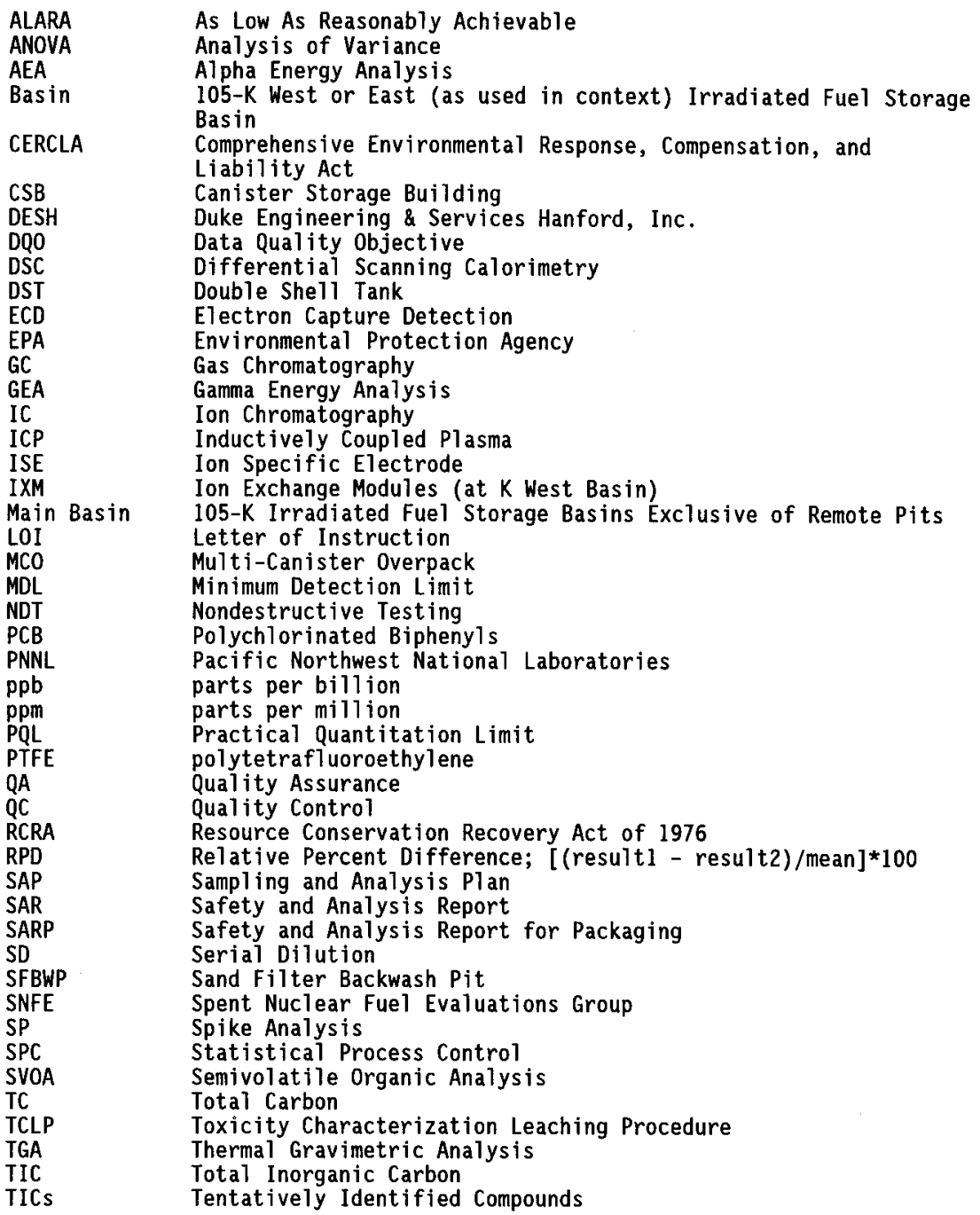


HNF-SD-SNF-PLN-020, Rev. 0

\section{LIST OF TERMS (Continued)}

TIMS

TLD

TOC

TSCA

TWRS

VOA

WHC

XRD
Thermal Ionization Mass Spectroscopy Thermoluminescent Dosimeter Total Organic Carbon

Toxic Substances Control Act

Tank Waste Remediation System

Volatile Organic Analysis

Westinghouse Hanford Company

$X$-Ray Diffraction 
HNF-SD-SNF-PLN-020, Rev. 0

\section{SANPLING AND ANALYSIS PLAN FOR SLUDGE LOCATED IN FUEL STORAGE CANISTERS OF THE 105-K WEST BASIN}

\subsection{SAMPLING OBJECTIVES}

\subsection{PURPOSE}

The purpose of this sampling and analysis plan (SAP) is to define the strategy and the methods that will be used to sample and analyze the sludge located in the closed fuel storage canisters of the 105-K West Basin. The data quality objectives (DQOs) for the sludge sampling campaign are provided in (Makenas 1996a). Canister sludge in $K$ West is assumed to be a nonhomogeneous mixture of particulate materials likely containing fuel element fragments and corrosion products, fuel storage canister corrosion products, and/or fission products. The sludge may also contain to a much lesser degree environmental materials such as sand and insects, and materials accumulated during past basin operations when lids were removed (including periods of handling in $N$ Reactor Basins prior to storage in $K$ West Basin).

Specifically this SAP contains (1) the background on the plan used to acquire nine samples of sludge from $K$ West Basin fuel storage canisters ("canister sludge"), and (2) the planned requirements for the analytical laboratories to subsample and analyze these nine samples.

1. Background on Initial Sample Acquisition Activities: At this stage of the sampling campaign nine samples have been successfully collected from $K$ West Basin canister barrels and these samples, in special sample containers, have been transported to the Hanford 325 Analytical Laboratory. The sealed sample containers are being prepared first, for collection of any gas generated from the samples and second, for recovery of the sludge sample material and corresponding water. To provide an integrated summary of the total sampling campaign this SAP provides a summary of the initial activities and requirements used to acquire these samples. These initial activities are following requirements and criteria specified by the: DQ0 document (Makenas 1996a), K Basins Master Work Plan (MWP-95-005), K Basins Sampling procedure (OP-07108W), canister choices memo (Baker 1996b), and corresponding canisters choices document (Makenas 1996b) for this sampling campaign.

2. Plan for Detailed Laboratory Analyses of Samples: The primary purpose of this SAP is to provide the specific requirements for detailed subsampling and analysis of the nine sludge samples after completion of initial acquisition activities noted in the previous paragraph. These laboratory requirements form the general scope (i.e., specific laboratory procedures, accuracies, etc.) and criteria (i.e., Quality Assurance, reporting, etc.) for the analyses of the $K$ West Basin canister sludge samples. Letters of Instruction, LOI, will be written to the laboratories to supplement 
this SAP. These LOIs will provide instructions to the laboratories on exactly which samples are to receive a particular analysis (as specified in this SAP) and any special handling the samples should receive based on how analyses proceed. The final results of the laboratory analyses will provide the final documented data satisfying the needs identified by the DQO document.

Basic to this sampling campaign is the basis for the canisters sampled for sludge. The DQO document (Makenas 1996a, Section 2.4 .2 and 2.7) and the canister choices memo (Baker 1996b) contain the rational for this. Additional discussion of this selection process is provided as background in Section 2.2.1 of this SAP.

A SAP (Welsh 1996) similar to the current document was previously written for the $K$ East Basin canister sludge characterization. The $K$ East Basin fuel storage canisters differ from $K$ West primarily because the former are not closed and have been exposed to the basin pool throughout their extended period of storage. In addition, the $K$ West Basin canisters had corrosion inhibitor injected in the canister water prior to sealing. This and other refinements make the $K$ West Basin a potentially cleaner system than the $K$ East Basin situation (see Baker 1995b, Appendix A).

\subsection{SAMPLING AND ANALYSIS ACTIVITY OBJECTIVE AND GOALS}

The DQ0 document (Makenas 1996a) for this activity summarizes the objectives and logic relating this sampling effort to key Spent Nuclear Fuel (SNF) project activities. The basic decisions requiring this characterization are related to (1) the handling and behavior of canister sludge during retrieval and removal of fuel at $K$ West Basin, (2) the retrieval, storage, and disposal of $K$ West Basin sludge (both canister sludge and canister sludge subsequently mingled with floor sludges), and (3) the impact of residual canister sludge accompanying spent fuel elements to the Canister Storage Building (CSB) in Multi-Canister Overpacks (MCO). The specific characterization decisions are:

1. What are the physical properties and composition of the $K$ West Basin canister sludge related to the sludge being passed through the ion exchange modules (IXM) at the basin, as the fuel is retrieved and handled. In passing through the IXM a portion of the sludge will be captured in the IXM and a portion will escape to return to the water in the basin pool. Design issues include the potential need for pre-filters, numbers of IXMs that will be used (i.e., resulting in solid waste when disposed), validity of assumptions on hazardous waste [e.g., metals related to the Resource Conservation Recovery Act of 1976 (RCRA)] content of IXMs, and impact of water clarity because of suspended sludge returned to pool (i.e., impact on overall fuel retrieval efficiency).

Sampling Goals: Obtain samples of sludge from nine spent fuel canisters which represent a range of fuel types, canister types, canister sludge depths, and cesium concentration from the canister 
barrel water samples (reflecting potential levels of fuel element damage). The samples will be delivered to the Hanford Analytical Laboratories. Aliquots will be subjected to physical property testing, chemical analyses and analyses for selected isotopic composition at the Hanford Analytical Laboratories. These analyses will provide confirming data for design assumptions being used by the Spent Nuclear Fuel (SNF) project.

2. What hydrogen generation rate is observed from the canister sludge and what are the hydrogen producing species? What other gases are produced by the canister sludge? These issues are directly related to the ability of the IXM design to dissipate gases safely. This gas generation (maximum rate and potential rate over time) is also a concern to the SNF project fuel handling process design and the potential option of disposing the sludge to a Double Shell Tank (DST).

Sampling Goals: Obtain representative samples of $K$ West Basin canister sludge and monitor the production of gases at the different steps after acquisition. When samples are at the Hanford Analytical Laboratories, testing methods will be provided to capture samples of gases evolved (1) initially in the sludge sample shipping containers and (2) during sludge settling studies. The general rate of gas formation (i.e., volume per hour or minute) and the composition of the gas generated by the sludge samples, if any, will be determined. Both the mass of the sludge producing the collected gas and its temperature at this point in time wi11 also be determined as the samples are analyzed.

3. Does the $K$ West Basin canister sludge meet established acceptability criteria for storage and disposal in the Hanford Tank Waste Remediation System (TWRS), specifically in one or more DSTs? (A secondary consideration here is the potential backup alternative of the sludge being dispositioned as solid waste. In either case the sludge would be stored and then follow the related waste to ultimate disposal in a permanent repository.)

Sampling Goals: Obtain representative samples from nine canisters. Aliquots will be submitted for analyses to determine chemical and isotopic compositions of selected constituents. Gross physical properties of sludge will also be obtained from the samples (e.g., settled density, volume, weight, settling time, behavior of selected layers, particle size, etc.). This will provide estimates of the analyte concentrations considered necessary by TWRS (e.g., Fowler 1995a, 1995b; Alderman 1997; Williams 1996) to allow their review and acceptance of the sludge for placement in a DST. It will also provide estimates of analyte concentrations important to successful handling of sludge as solid waste (Willis 1993). 
4. What actions if any, must be taken during the drying, conditioning, and storage of $K$ West Basin spent fuel elements in MCOS as a result of residual canister sludge which accompanies the spent fuel elements?

Sampling Goals: Obtain drying data from representative samples of canister sludge that are meaningful to pending decisions on proposed drying and conditioning parameters for the fueled MCOs. Quant ify any toxic constituents that potentially influence permitting or final disposal of the fuel elements.

5. What is the best choice of equipment to successfully retrieve, handle (e.g., pump, etc.), and process canister sludge?

Sampling Goals: Obtain fluid and rheological properties which characterize $K$ West Basin canister sludge samples to allow accurate development and qualification of designs for sludge handling equipment (i.e., transport, processing, etc.). This will also provide required information for developing suitable simulants for equipment development and testing.

6. Can a nondestructive test method, such as portable gamma scanning, provide an acceptable measure of the fissile content or of marker radionuclides consistent with the fissile accountability needs for $K$ Basin canister sludge handling and receipt? (This was not directly addressed in the DQO but is inferred in Table 1 of that document under isotopes of europium).

Sampling Goals: Obtain relationships between fission product radioisotopes (measurable by gamma scan methods translatable to field applications) and plutonium concentration (measured by analytical laboratory methods) in $K$ West Basin canister sludge samples such that, if possible, one or more of the fission products can be identified as a marker for plutonium when quantifying residual transuranics in the sludge. These data will be combined with results from similar analyses made on $K$ East Basin sludge, to verify the test method is viable.

It should be noted that the current draft of the "Memorandum of Understanding for $K$ Basin Sludge Transfer to Tank Waste Remediation System," between the SNF project and TWRS, agrees TWRS will provide complete acceptance criteria for the DST. The final characterization needs for $K$ West Basin canister sludge, if it is dispositioned to a DST, may increase over the current basis (Fowler 1995a, 1995b) once the final criteria are developed (e.g., Williams 1997). Additional characterization was eventually required for the K East sludges (e.g., Alderman 1997) beyond the original SAP. These additional characterization needs (e.g., repeating some analyses with $K$ West Basin sludge mixed with DST tank waste, thermal conductivity of sludge material, etc.) will likely be accommodated with the planned contingent sample volume that should be available from this sampling campaign. Additionally, no standard analytical methods or procedure(s) were 
identified to obtain some information that may be required by TWRS (e.g., total hydrogen yield at reaction completion per unit of sludge as it comes from the basin, confirmation of XRD results for uranium/zirconium metal, and hydride concentrations, etc.). Methods to obtain this information will continue to be investigated. Any analyses subsequently performed will be documented separately. This documentation will include both the planning basis and data reports. 
HNF-SD-SNF-PLN-020, Rev. 0

This page intentionally left blank. 
HNF-SD-SNF-PLN-020, Rev. 0

\subsection{5-K EAST BASIN STATUS AND SAMPLING INFORMATION}

\subsection{5-K WEST BASIN STATUS}

The 105-K West Basin was designed and constructed in 1950 to 1951 . The purpose of the basin was to receive and store irradiated fuel from the $K$ West reactor. The basin provided the freshly irradiated fuel with cooling and a 150-day period of time to allow short-lived isotopes to decay. The water in the basin provided the workers with shielding from the nuclear radiation resulting from the isotope decay while they sorted and handled the fuel elements underwater.

The $K$ West reactor stopped the irradiation of fuel in 1971. In 1976, the basin started receiving irradiated fuel from the 105-N Basins. The fuel was stored in the basin in closed twin barreled canisters (Baker 1995b). A portion of this fuel is still stored in the basin today, and some fuel elements have breached cladding such that significant corrosion of the exposed uranium fuel material may have occurred. These corrosion products are primarily hydrolyzed metal and deteriorated fuel compounds that precipitate as a flocculent sediment in the bottom of the canister barrels and may be partially released to the basin when lids are removed.

The only analyses of sludge in the $K$ West Basin has occurred on (1) floor sludge from the Sandfilter Backwash Pit (i.e., North Loadout Pit) and (2) trace amounts of sludge that accompanied fuel elements removed from canisters in 1995 (Makenas 1996a). Item 1 relates to periodic cursory sampling made on the sludge in the Sandfilter Backwash Pit which contains on the order of $4 \mathrm{~m}^{3}$ of sludge (depths of up to about $1 \mathrm{~m}$ ). A summary review of this limited sludge data for $K$ West Basin is provided (Baker 1995b).

As part of the $K$ Basin characterization effort a number of the sealed canister barrels have been sampled for gas and water. Of concern was the gas composition related to hydrogen, cesium fission products in the water, and the levels of corrosion inhibitor remaining in the canister barrel water. Inhibitor was injected into the barrels as they were initially closed. The DQO document (Makenas 1997a) for this canister sludge characterization effort provides additional background on the condition and proposed processing of the canister sludge at $K$ West Basin.

A summary is currently being written to document selected measurements made of canister sludge depths completed prior to the sampling of sludge in the canisters at $K$ West Basin. However, the ultrasound measurement of sludge depths in the canisters were inconsistent (perhaps due to complications caused by materials used to seal the canister lids falling between the fuel elements during lid removal). A recent review concluded the use of measured concentrations of cesium in the water of these canister barrels, prior to opening, provided a better basis for estimating the volume of fuel that had turned to sludge (Trimble 1997b). The total volume of sludge projected from this basis for the $K$ West Basin canisters was found to be $1.7 \mathrm{~m}^{3}$ for a working 
estimate, with a bounding estimate of $3.0 \mathrm{~m}^{3}$. Results of visual examinations of the fuel elements contained in the $K$ West Basin canisters analyzed for sludge depths and sampled for sludge analyses are provided (Pitner 1997).

During the ultrasound measurements of sludge depth in the canisters, the condition of the fuel elements was also assessed by lifting the elements out of the barrels carefully and video taping their exterior condition. From these examinations, in addition to fuel cladding condition, it was possible to assess some indicators related to sludge condition in the $K$ West Basin canister barrels. Observations included sludge clinging to the fuel elements, sludge escaping from the cracks in fuel elements, clouds of sludge observed during handling the fuel elements and lids, and marks (i.e., rings) on the fuel elements that might be representative of sludge depths. This evidence of sludge in the canister barrels was ultimately added to the other knowledge used in selecting which canister barrels were sampled for canister sludge.

The final set of parameters considered in selection of the nine canister barrels to sample included:

- Canister type (Mark I or Mark IA)

- Fuel type in canister

- Fuel condition in canister based on observations

- Cesium concentration measured in samples of water taken prior to opening

- Measured depth of sludge by ultra sound techniques

- Condition of the sludge based on observations video taped during prior examinations.

These were considered in the final canister selection process (Makenas 1997b). The objective of the selection process is to sample a set of canisters that are as representative as possible of the objectives noted in Section 1 .

\subsection{5-K EAST BASIN SLUDGE CHARACTERIZATION STATUS}

Information from characterization of $K$ East Basin sludge may be related directly to the $K$ West Basin canister sludge. For $K$ East Basin, main basin floor and Weasel Pit sludge was characterized based on 20 samples taken in 1995 (Makenas 1996c). In addition nine samples of sludge from $K$ East Basin fuel storage canisters were subsequently taken and are being characterized through the laboratory analyses (Welsh 1996). The nine canister samples were determined to be a sufficient number to compare the mean property measurement values from the canister sludge to those of the floor/pit sludge. 
Similarly, it is expected that because of less overall variation in the $K$ West Basin canister sludge parameters, a set of nine samples should also provide a basis from which to judge any major deviations of $K$ West Basin canister sludge from sludge in K East Basin. While there should be a number of direct relationships between the characteristics of $K$ East Basin and $K$ West Basin sludge, there are also anticipated differences. These result from the (1) "closed" or sealed canister barrels in the $K$ West Basin system versus the open top (and in some cases open bottom) canister barrel system in K East, (2) $K$ West Basin being overall a more "clean" system as the closed barrels retain most of the fuel related materials, (3) the $K$ West Basin has coated concrete walls while K East Basin does not, and (4) differences of the fuel types stored in each basin. An example of the anticipated differences is that the $K$ West Basin canister sludge is expected to be even higher in fuel components than $K$ East Basin canister sludge. This results because there are no extraneous materials (e.g., dust, sand) being deposited into the canisters from surrounding basin operation. The primary source of sludge material in $K$ West Basin canisters should be the decomposition of the fuel elements.

For reference, the following paragraphs provide a summary of the status of characterization in the $K$ East Basin with respect to sludge.

The $K$ East Basin floor sludge was periodically sampled prior to 1995. Analytical results (Baker 1995b) have shown the material to contain predominantly sands, ferric oxides, aluminum oxides and uranium oxide residuals. The sludge has also been found to contain trace amounts of barium, cadmium, chromium, lead, and samarium. Finally, the sludge is known to contain plutonium based on analysis of materials collected from the 105-K East Sand Filter Backwash Pit (SFBWP) and its transfer channel (Bechtold 1994).

Measurements of floor sludge depths in the 105-K East Main Basin were made in 1994 and have shown that the basin floor is covered with sludge to a depth of 5 to $19 \mathrm{~cm}$ (Baker 1995b) and that the Weasel Pit is covered with sludge up to a meter or more in depth (Makenas 1996c). Potential local sources of sludge that could influence the floor sludge characterization were evaluated by the Spent Nuclear Fuel Evaluations (SNFE) group, (Baker 1995c). The local sources considered were:

- Fuel sludge passing through openings in canisters containing breached fuel elements

- Corrosion of the aluminum canisters

- sloughing of the unsealed concrete walls that form the basin

- Flaking paint off the fuel storage racks

- Historical activities (e.g., fuel handling) affecting areas near the mouth of the pits (i.e., Weasel Pit, Tech View Pit, Dummy Elevator Pit, and South Load-Out Pit). 
Detailed sampling and analyses were recently completed for the floor sludge in the K East Main Basin and Weasel Pit. These results are reported in detail (Silvers 1995; Miller 1996) with a final report completed May 1996 (Makenas 1996c). General results agree with expectations with the exception of the unexpected identification of polychlorinated biphenyls (PCBs) in some of the sludge samples.

Some similarity is expected between the sludge in the $K$ West Basin canister samples and samples that may contain canister sludge taken from the K East Basin. This includes: (1) all the K East Basin Weasel Pit sludge samples (2) the floor sludge sample taken from between canisters (KES-0-09), and (3) the sludge samples taken recently from the canister barreis. The Weasel Pit has sludge that was pumped into it from the Segregation-Discharge Chute area. Since the Segregation-Discharge Chute area was used in the past to dump out canister barrels to recover fuel elements, sludge from the canisters was likely included in the accumulated sludge on the floor in this area. However, there is no way of knowing the canister sludge dilution once mixed with the floor sludges in both the Segregation-Discharge Chute and the Weasel Pit. Similarly, the KES-0-09 sample was taken near breached fuel elements and showed a high concentration of fuel related materials. While this sludge is likely similar to canister sludge the dilution it would have in the "normal" components of the floor sludge is unknown.

In 1996 a characterization campaign was begun to obtain definitive data on $\mathrm{K}$ East Basin canister sludge. To better understand the general character of the canister sludge a survey was made of over 50 canister barrels for (1) fuel element condition (accomplished by visual inspection using underwater video cameras) and (2) sludge depths (measured by ultrasound techniques).

The survey (Pitner 1996) provided definitive information to assist in canister selection.

The primary objectives of the analyses of the canister sludge in $K$ East Basin were verification of (1) its general similarity in dependencies and composition to the floor sludge, and (2) establishment of those areas where its characteristics differ from floor sludge. Variables considered for the selection of candidate canister barrels sampled for sludge were:

- Condition of fuel elements in barrel (e.g., cladding degradation, damaged fuel, etc.)

- Age of fuel in barrel

- Condition (e.g., corroded) and material (e.g., aluminum) of canister barrel

- Type of canister barret (e.g., open bottom, slotted, etc.)

- Depth of sludge in barrel.

The analysis of the $K$ East canister sludge samples is currently being completed. Two initial observations related directly to the proposed $K$ West canister sludge analyses are: (1) sludge samples generated gas both in some 
of the shipping containers and during the settling studies, and (2) samples contained very high concentrations of fuel (e.g., uranium concentrations in dry canister sludge material as high as $65 \mathrm{wt} \%)$. The gas formed in the K East canister sludge was found to be hydrogen with traces of fission gases and tritium. This leads to the conclusion that unreacted uranium metal fuel was present, however no such fuel was detected in the samples which received X-Ray diffraction (XRD) analyses. This lack of confirmation may result from there only being a comparatively few particles of uranium or that the particles are quickly coated with an oxide layer masking the uranium from the XRD analysis.

\subsection{SAMPLING INFORMATION}

\subsubsection{Sample Collection and Handling}

The sampling will be conducted such that the operation does not impact the water quality/air emissions at the $K$ West Basin. The sampling apparatus is described in the System Design Description document (Baker 1996). The sludge sampler utilizes specially developed equipment made to sample sludge from the fuel storage canister barrels while keeping the sample at least 10 feet under the surface of the Basin water pool, Figure 1. The design has been developed and cold tested to meet criteria including showing the ability to collect high density materials such as uranium sludge. The sampler is basically composed of a sealed sample container (which is also used as the sample shipping container) of approximately 10 liters, constructed of stainless steel having "quick disconnect" inlet and outlet ports on the 1 id. The outlet is attached to a pump that evacuates the air from the sealed sample container. The inlet is attached by flexible tubing to a specially developed extraction tube with nozzle assembly that can be inserted into a fueled canister barrel and the sample collection controlled by an operator standing above on the Basin grating.

The nozzle is designed with openings to restrict particles larger than $0.25 \mathrm{in}$. $(0.64 \mathrm{~cm})$, leaving them in the canister. The nozzle is controlled by a valve which when opened during sampling, allows sludge to be pulled into the sample container under the force of the established vacuum in the sample container. The sludge material is minimally disrupted by this sampling technique. The extraction nozzle is guided down the channel between the fuel elements and the canister barrel wall (or in some cases down the center of "outer" fuel elements). Collection of the sludge is made to the bottom of the barrel in each channel before moving on to the next channel. The sample containers are specially cleaned prior to use to minimize possible contamination from fabrication processes (Bridges 1996).

It is planned that each sample of canister sludge be about $500 \mathrm{ml}$ of as-settled sludge, approximately double the size of floor sludge samples taken previously at K East Basin (Baker 1995a). This should provide enough sample for analyses called for in this SAP, plus contingent sample volume to use for future tests including such potential process demonstration tests as mixing studies of $K$ West Basin sludge combined with TWRS DST sludge (Alderman 1997). 
HNF-SD-SNF-PLN-020, Rev. 0

Figure 1. Overview of Canister Sludge Sampling Equipment.
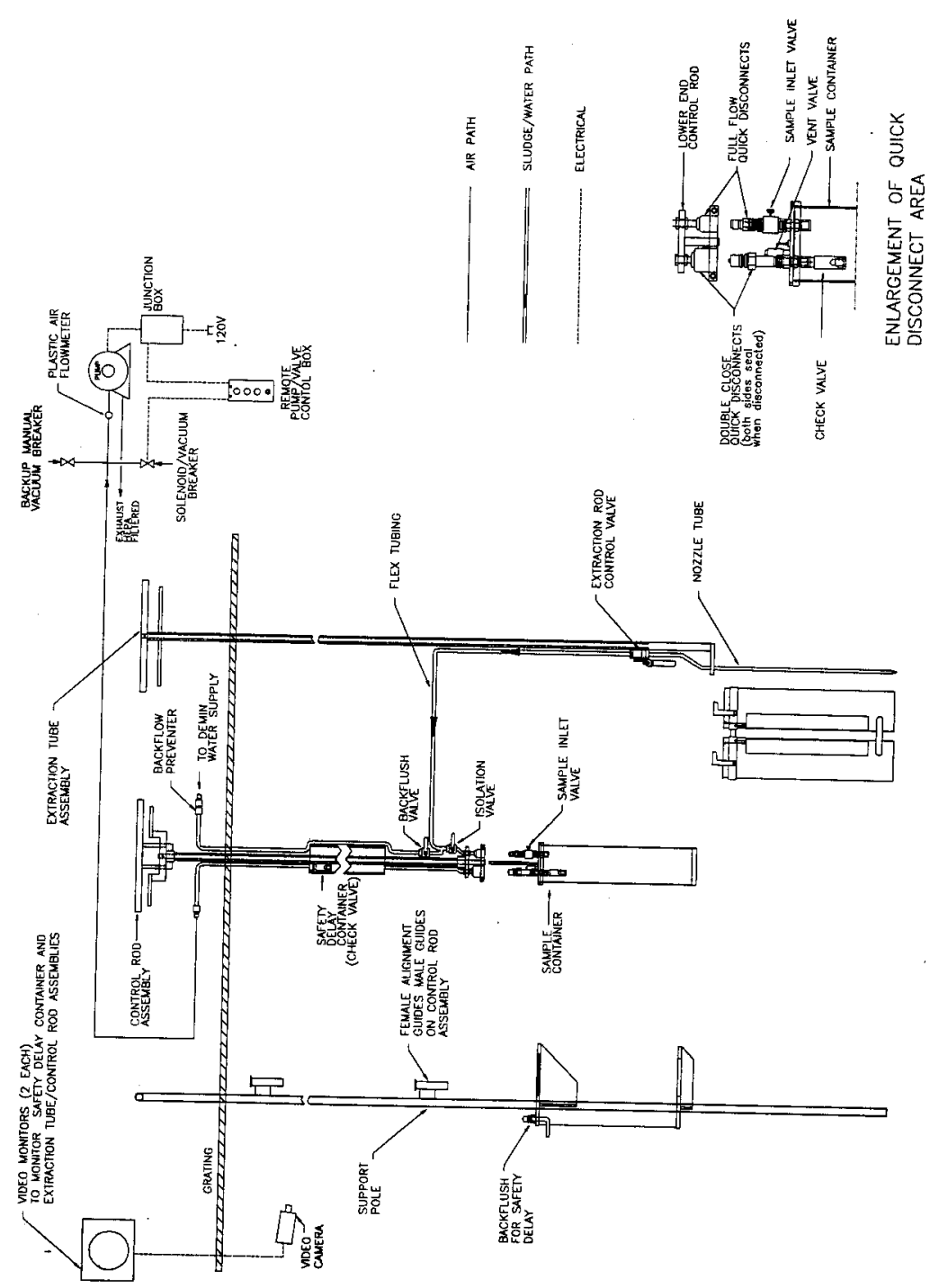
The sampling team followed approved sampling procedures during the collection of the samples. Detailed descriptions of the sampling apparatus and methodology is provided in the sampling procedure ( $K$ Basins 0P-07108W) and Master Work Plan (K Basins MWP-95-005).

At this time the nine samples of $K$ West canister sludge have been taken from selected canisters. Each sludge sample container is labeled with a unique number. The SNFE group Test Engineer verified that the samples were properly identified and the sample location was recorded prior to moving the sample from the 105-K East Basin area. The SNFE group Test Engineer ensured that the sample custody during transportation complied with the requirements defined in K Basin procedure MWP-95-005. After the sludge samples were collected, they were moved to the area in the $K$ West Basin pool used for hydrogen generation checks and subsequently moved to the Chem-Nuclear cask

for transport to the Hanford laboratories. The packaging of the samples complied with applicable DESH procedures.

There is no analytical hold time limit on the samples. It was the intent to ship the samples to the analytical laboratories as quickly as possible. If logistics precluded shipment within 1 month from the date of sampling, the SNFE group Project Coordinator would have evaluated the situation to confirm applicable storage for the samples. Currently the samples have been shipped and are being processed at the 325 Laboratory.

Once in the laboratories the samples will be sealed hermetically to avoid evaporation but caution must be used to preclude any excess gas generation in containers. Because chemical preservation steps do not make allowance for slurries and would adversely affect the sample (pH change), chemical preservation of samples will not be performed.

It is planned that (1) the analytical laboratories will dispose of the remains of the sludge and water from analyzed samples once the analyses are complete and (2) any significant quantities of sludge not used for analyses will be returned to $K$ Basin if no additional analyses or testing is anticipated. Any use of excess sampled water or sludge by other programs must be approved by the Project coordinator and results of such studies provided to the SNFE group.

\subsubsection{Sample Record Keeping}

A vital part of the sampling activity is the assurance that all of the information and data associated with each sample are accurate and verifiable. Therefore, all pertinent information and data collected during the sampling and sample breakdown will be recorded. The pertinent data to be collected and the corresponding records will be maintained in accordance with the requirements of the sampling procedure (K Basins OP-07108W), the Master Work Plan (K Basins MWP-95-005), and the QA at the laboratory doing the sample breakdown (i.e., PNNL QA PIan MC-033). Chain of custody forms will be used at each step of collection and transfer by field and laboratory personnel (i.e., required in K Basin Master Work Plan, LOIs, etc). The LOIs for the sampling effort may also provide additional direction on record keeping. 
HNF-SD-SNF-PLN-020, Rev. 0

\subsubsection{Field Sample Plan Modifications}

Any modifications to the sludge sampling plan made in the field must be made/approved by the SNFE group Test Engineer and/or SNFE group Project Coordinator, and documented. Changes affecting quality related information will include QA approval.

\subsubsection{Sampling Locations}

Representative sludge samples were obtained from nine fuel storage canister barrels containing fuel elements. The DQO document (Section 2.4.2) provides a general basis for the number of samples taken. It is intended to compare the mean concentration values of the recent $K$ East Basin floor sludge sample analyses with the statistical mean values resulting for the $K$ West Basin canister sludge samples analyses.

Consistent with the plans for the $K$ East Basin canister sludge analyses (Welsh 1995), (as well as the K East Basin floor and Weasel Pit sludge analyses) two categories of samples will be used: "normal" and "research." After settling studies are completed for all nine samples, nominally, seven will be chosen as "normal" samples and two as "research." The research samples will be chosen to represent typical range of resettling behavior. Normal samples will be settled and homogenized by stirring, followed by the designated set of analyses. The research samples will establish the influence of re-settled layers of sludge through additional analyses, beyond those planned for the "normal" samples. Further discussion on "research" samples is provided in Sections 2.3.5 and 3.1.

The locations and the rational for canisters selected for sampling are described in the Canister Choices document (Makenas 1996b). This document considers currently available data and rationale for use of the data from the visual and $u l$ trasound survey made at $K$ West Basin shortly before sludge sampling of the canisters. The selection of the canister barrels to sample addressed the parameters discussed in Section 2.1.

As noted in Section 1.0 the $K$ West canister barrels are closed or sealed by a lid with a corresponding gas release system to keep them from pressurizing during storage (Baker 1995). Each barrel typically contains seven inner and seven outer fuel elements (Makenas 1996a). In order to sample the sludge in the bottom of the canister barrels, the sealed lids must be removed. This is done with special tooling that pressurizes the barrel with water lifting the lid. During the course of this process some sludge in the barrel is disturbed and can settle outside the canister barrel. This same behavior occurs as fuel elements are moved to be viewed outside the barrel. Review of video tapes of the lid removal and fuel examination activities indicate that the potential loss of sludge from the barrel is minimal (i.e., acceptable), and should not result in significant impact to the sludge analyses. The loss of sludge appears general (i.e., does not appear to eliminate one particular component of the sludge) and the 1 id removal was made as gentle as possible. Further, the review of fuel elements allowed better understanding of the sludge, allowing more representative choices of canister 
barrels to be sampled for sludge than would otherwise be possible (i.e., the resulting sludge samples are more representative of canisters with significant sludge volume than would be possible by randomly sampling "similar" barrels).

\subsubsection{Sample Preparation}

Procedure(s) or test instructions for sample preparation, similar to those used for the K East Basin canister sludge samples (i.e., PNNL "K East Canister Sludge Settling, Test Instruction," dated July 11, 1996), will be prepared by the analytical laboratory performing the analyses. The sample preparation procedure will contain the detailed instructions necessary to safely and properly record observations, monitor gas generation if present, decant and subsample (as needed), digest (if necessary), handle, package, and label each sample and its derivatives in the hot cell/hood. The SNFE group Project Coordinator will concur with the procedure prior to its application.

The sample preparation (for ICP, GEA, etc.) may involve drying the sample in a polytetrafluoroethylene (PTFE; teflon) beaker on a hot plate and then an acid digestion. Therefore, subsamples for organics analyses and other analyses affected by either drying or acid digestion (TIC, TOC, TC, DSC, IC, XRD, etc.) need to be obtained prior to sample preparation. In some cases, as specified in the LOI, the liquid portion and the wet sludge should be sampled for the various analyses.

The "norma1" and "research" samples differ in that the research samples will be separated for analyses of individual layers. A "normal" sample will be homogenized and analyses will be performed on the integrated properties. The "research" samples will be separated into major "layers" and each layer analyzed. This is necessary for meaningful rheology measurements and is of interest for possible impact of settled layers behaving differently than the mixed mass of the sample (e.g., plutonium concentration). Layers will be identified as was done for the recent $K$ East Basin floor sludge and canister sludge samples--that is a visual identification by color and/or texture of regions of sludge material appearing as stratum after settling studies are completed. Typically two or three layers were found in the $K$ East Basin sludge samples.

Analysis of all the sludge samples by layers was considered. This was done in order to determine the possible effects such as plutonium being distributed differently between the heavier and lighter sludge layers. It was, however, concluded the limited number of research samples (at least two) would be sufficient. Factors involved in this decision (not analyzing by layers in all samples) included: difficulty in objectively determining layers, settling differences between the evolving material in the basin versus using all the material at once in the analytical laboratory, a desire to maintain the maximum sample quantity to minimize potential for inhomogeneities when splitting, and lack of objective data concerning the distribution of the heavier components. This decision also assumes that if the sludge material in the basin passed through the IXMs (and/or filters) the sludge behavior will not be strongly related to the settled layering in the laboratory. Also, if 
the sludge is transferred to tank farms or sent to solid waste disposal, it will be sent initially as a mixture, although some separation into layers may occur in transit and after deposited in the DST.

The analytical laboratory will document and photograph both the appearance of the research samples and the number of layers or strata seen based on appearance (e.g., color, texture, etc.). The samples will be reviewed after the settiing studies to choose research samples. If unique layering is noted more than two research samples may be chosen. The decision to have more than two research samples will be the responsibility of the SNFE Project Coordinator after consulting with 325 Laboratory scientists, SNF project staff, and the manager of the SNFE group. The decision will be documented by LOI to the laboratory.

For each sludge research sample the laboratory preparation personnel will separate the sludge layers into different sample containers. After separation, each layer will be processed according to the laboratory sample preparation procedure, which will be defined in the LOI and approved by the SNFE Project Coordinator prior to application. These "research" samples will be chosen to be similar to previously selected "normal" samples, so that general comparisons can be made between the samples handled as one unit and those handled in layers. It is very important that the analytical laboratories measure and record the evolving densities of the canister sludge samples (i.e., as-settled, centrifuged, dried, etc.). These densities will allow both comparison to past work (Miller 1995, 1997; Silvers 1995, 1997) and the state of sludge as collected. 
HNF-SD-SNF-PLN-020, Rev. 0

\subsection{LABORATORY ANALYSIS INSTRUCTIONS}

\subsection{GENERAL}

Specific instructions on processing of each canister sludge sample in the analytical laboratories will be provided by letters of instruction (LOI) from the SNFE group Project Coordinator prior to shipment of samples.

Each sludge sample may be analyzed to ascertain properties such as fissile and fission product content for criticality, shielding and accountability.

Each sludge shipping container will be received by the analytical 1 aboratory and monitored for gas generation (i.e., rate of generation-cc/hour and composition) for a reasonable period (e.g., at least 2 days). The sludge samples will then be recovered from the shipping containers and prepared for settling studies. During the settling studies gas generation will again be monitored and quantified, if present, for both formation rate and composition. High resolution video tape will be made of samples if gas generation is observed and during settling studies.

Special glass gas traps were developed to capture the released gas and provide a visual indication of the volume (cc) generated which will be recorded on video tape. The gas traps will be used with both the sample containers and settlers to measure gas generation rates. Some of the sludge physical properties (e.g., settling rate) will be obtained prior to any subsampling efforts. Other properties (such as viscosity and particle size/shape) must be determined from aliquots taken prior to centrifuging. After centrifuging (prior to heating or acid digestion), aliquots of both the liquid and the solids will be obtained from each sample. These aliquots will be used by the laboratory for organic, TIC, TOC, XRD, DSC, TGA, and other analyses sensitive to either drying or acid digestion. An aliquot of the thoroughly stirred dried sludge, of sufficient weight (about $10 \mathrm{~g}$ ) to minimize sample heterogeneity, will then be processed through an acid digest stage. An aliquot of the acid digested sludge shall be prepared and sent to the laboratory. Any solids which remain after the acid digestion step will be analyzed by XRD and if there is sufficient quantity also subjected to caustic fusion and analyses.

The laboratory will analyze each aliquot in duplicate or as directed in Section 8.0 of the SAP or the LOI. Each subsample taken from that al iquot must go through separate sample preparation, if sample preparation is required. If a sufficient amount of dried sludge is not available for the acid digestion step, then analyses for that sample may be 1 imited to higher

priority data. The laboratory should subsequently document the reason for not performing any of the analyses called for in the Lol in the narrative of their data report. An alternative to not performing the analyses is to have $K$ Basin operations take additional samples for the "other" required analyses. The choice of not performing analyses or requesting additional samples will be at the discretion of the SNFE group Project Coordinator. 
A flowchart showing the general analysis scheme for the sludge samples in the laboratory is presented in Figure 2. The analytical tests for the analytical laboratory work are shown in Table 1 . The reason or need for each of these analyses is defined in the DQO, (Makenas 1996a). In general the samples designated as "normal" will receive all the analyses in Tables 1 and 2 with the exception of those related to rheology measurements. The "research" samples will be split into samples of the observed layers or strata and these will each in general receive all the analyses in Tables 1 and 2 including rheology measurements (also see Sections 2.3.5 and 3.1). Note that no analyses for waste designation are called for in the DQO (see Section 2.2 of that document). This follows directly from the assumption made by the SNF Project for $K$ Basin sludge that the waste designation will be made based on "process history." As discussed in the DQO document, pyrophoricity of the sludge is being assessed from the XRD measurements for metallic Zr, metallic $U$, and $U$ hydrides. Exothermic reactions are being evaluated by differential scanning calorimetry (DSC).

\subsection{ANALYSES}

Table 2 shows the analytes, methods, and the laboratory procedures required for the analysis of the samples. The tables also ilst the requirements for detection levels, precision, and accuracy of data results. Note that if dilution factors change from what is expected based on factors from recent $K$ East Basin floor sludge sampling (Miller 1995), the detection levels, precision, and accuracy values shown in Table 2 will have to be re-evaluated. One reagent blank will be run if required by the laboratory procedure for each analytical batch. An equipment blank from the $K$ Basin sample collection mockup will be analyzed for each set of new sampling equipment. At least one hot cell blank (if the hot cell is used) will also be analyzed. One method control standard will be run with each batch. A matrix spike will be run per matrix, where applicable, as indicated in Table 2 .

The analyses noted in Table 2 may be performed at either the 325 Laboratory or the 222-S Laboratory depending on capability, schedule, and costs. The LOI on the detailed analyses will define which laboratory will perform which analyses.

Additional analyses of the liquid fraction of the sludge samples, beyond those noted in Figure 2, are potential options to support (1) calculation of maximum theoretical leachate concentration for RCRA heavy metals, and/or (2) bench scale water/sludge processing concepts. These will be addressed in the LOI to the laboratories if they are to be performed. It is acknowledged that due to the potential dose rate of these samples such analyses could require significant additional preparation and costs at the laboratories.

Quality assurance (QA) and quality control (QC) information will conform to those required for a "full" data package (as discussed in the following paragraph). The QA/QC standards must conform to Table 2 and/or the applicable analytical procedures. The control standards, spike recoveries, precision between duplicates, hot cell blanks, and equipment blanks need to be within 
Figure 2. General Sample Analysis Strategy.

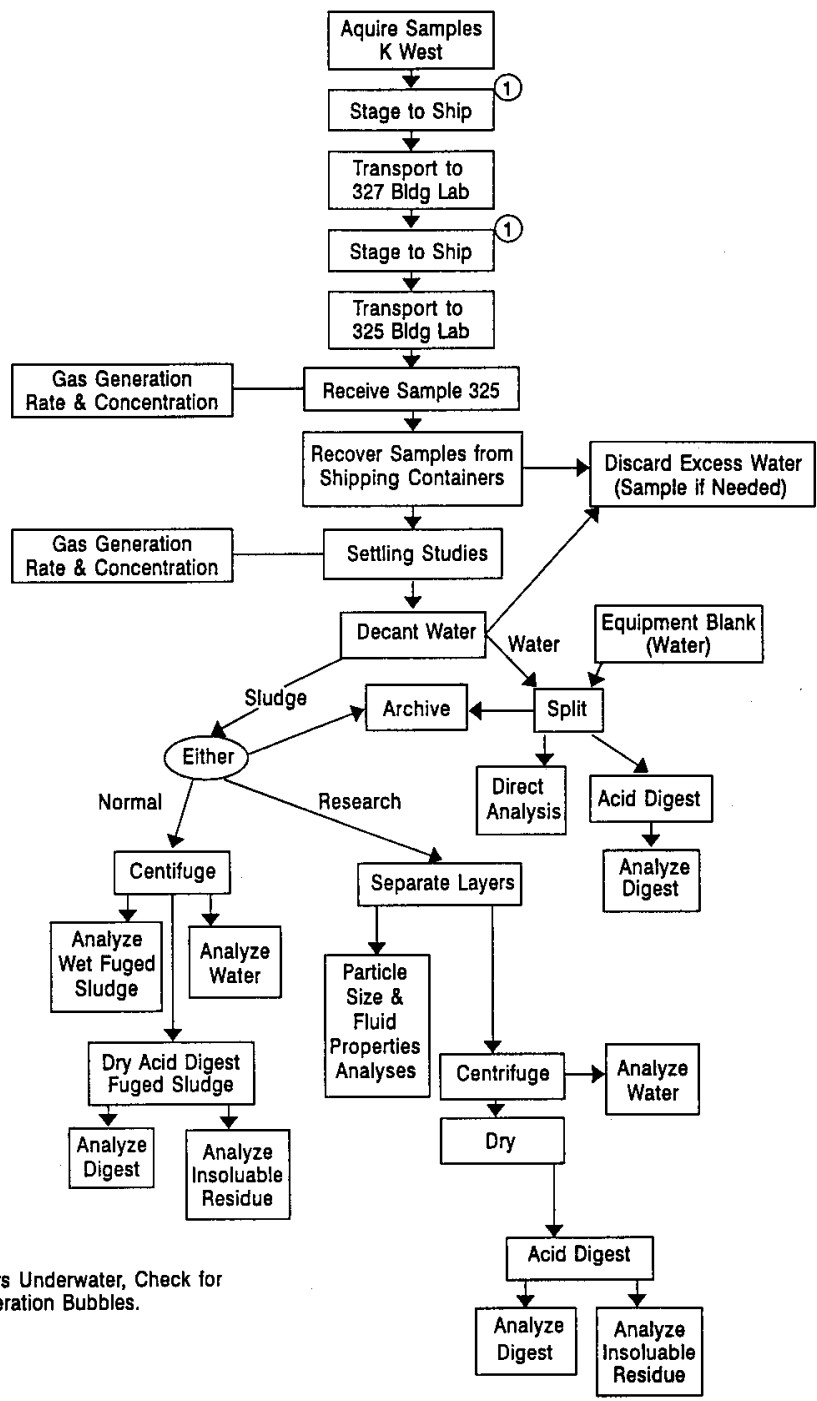


Table 1. 105-K West Canister Sludge Analyses for the Analytical Laboratory.

\begin{tabular}{|c|c|c|}
\hline Requested Analys is & Analysis Technique & Constituents to be Reported \\
\hline $\begin{array}{l}\text { Am-I sotopic } \\
\text { Pu-Isotopic }\end{array}$ & Separation and AEA & ${ }_{243 / 244}^{241} \mathrm{Am}$ \\
\hline Sr-90 & $\begin{array}{l}\text { Separation and beta } \\
\text { counting }\end{array}$ & ${ }^{90} \mathrm{Sr}$ \\
\hline $\mathrm{Np}-237$ & $\begin{array}{l}\text { Extraction and alpha } \\
\text { counting }\end{array}$ & ${ }^{237} \mathrm{~Np}$ \\
\hline Total Gamma & GEA & $\begin{array}{l}{ }^{241} \mathrm{Am},{ }^{134} \mathrm{Cs},{ }^{137} \mathrm{Cs},{ }^{60} \mathrm{Co},{ }^{152} \mathrm{Eu},{ }^{154} \mathrm{Eu}, \\
{ }^{155} \mathrm{Eu},{ }^{212} \mathrm{Bi},{ }^{208} \mathrm{Tl},{ }^{125} \mathrm{Sb},{ }^{226} \mathrm{Ra},{ }^{95} \mathrm{Nb}, \\
{ }^{106} \mathrm{Ru} / \mathrm{Rh} \text { and }{ }^{144} \mathrm{Ce} / \mathrm{Pr} \text { and other gamma } \\
\text { emitters in library }\end{array}$ \\
\hline Gross Alpha & $\begin{array}{l}\text { Gas proportional } \\
\text { counting }\end{array}$ & Detectable alpha emitters \\
\hline Gross Beta & $\begin{array}{l}\text { Gas proportional } \\
\text { counting }\end{array}$ & Detectable beta emitters \\
\hline U Total & $\begin{array}{l}\text { Laser fluorescence or } \\
\text { phosphorescence }\end{array}$ & Total uranium \\
\hline U Isotopics & TIMS & $\begin{array}{l}{ }^{233} \mathrm{U},{ }^{234} \mathrm{U},{ }^{235} \mathrm{U},{ }^{236} \mathrm{U},{ }^{238} \mathrm{U} \text { (al so report } \\
\text { avail able data on }{ }^{236} \mathrm{Pu},{ }^{259} \mathrm{Pu},{ }^{240} \mathrm{Pu} \text {, } \\
\left.\text { and }{ }^{241} \mathrm{Pu}\right)\end{array}$ \\
\hline Metals & ICP & $\begin{array}{l}\mathrm{Al}, \mathrm{Cd}, \mathrm{Sm}, \mathrm{B}, \mathrm{Fe}, \mathrm{Ba}, \mathrm{Cr}, \mathrm{Pb}, \mathrm{Ag} \text {, } \\
\mathrm{Be}, \mathrm{T}, \mathrm{Zn}, \mathrm{Cu}, \mathrm{Mn}, \mathrm{Mg}, \mathrm{Ca}, \mathrm{Na}, \mathrm{K} \text {, } \\
\mathrm{Se}, \mathrm{U}, \mathrm{Zr}, \mathrm{Bi}, \mathrm{P} \text {, and } \mathrm{Ni} \text { ( } \mathrm{Hf}, \mathrm{Sn} \text { if } \\
\text { in current analyses) }\end{array}$ \\
\hline IC Analyses & IC & $\begin{array}{l}\mathrm{NO}_{2}^{-}, \mathrm{NO}_{3}^{-}, \mathrm{PO}_{4}^{3-}, \mathrm{SO}_{4}{ }^{2-}, \mathrm{F}^{-}, \mathrm{Cl}^{-}, \mathrm{Br}^{-}, \\
\text {oxal ate, formate, and acetate }\end{array}$ \\
\hline Tc-99 & $\begin{array}{l}\text { Solvent extraction } \\
\text { with liquid } \\
\text { scintillation counter }\end{array}$ & ${ }^{99} \mathrm{Tc}$ \\
\hline Organics & SVOA & Any TICs found in the analysis, \\
\hline $\begin{array}{l}\text { Endothermic/Exothermic } \\
\text { Reactions }\end{array}$ & $\begin{array}{l}\text { DSC/TGA (use TWRS } \\
\text { method with nitrogen } \\
\text { and air cover gas, } \\
\text { and MCO method) }\end{array}$ & DSC/TGA include annotated thermogram \\
\hline
\end{tabular}


Table 1. 105-K West Canister Sludge Analyses

for the Analytical Laboratory. (Continued)

\begin{tabular}{|c|c|c|}
\hline Requested Analysis & Analysis Technique & Constituents to be Reported \\
\hline Settling Rate & Settling columns & Volume settled versus time \\
\hline $\begin{array}{l}\text { Polychlorinated } \\
\text { Biphenyls (PCB) }\end{array}$ & $\begin{array}{l}\text { PCB as near EPA } \\
\text { methods as reasonable }\end{array}$ & $\begin{array}{l}\text { PCB concentration in indicated solids } \\
(1 \mathrm{ppm}) \text { and water (1 } \mathrm{ppb})\end{array}$ \\
\hline $\begin{array}{l}\text { Settled and Centrifuged } \\
\text { Densities }\end{array}$ & $\begin{array}{l}\text { Gravimetric/sample } \\
\text { preparation procedure }\end{array}$ & $\begin{array}{l}\text { Settled density, volume, weight, and } \\
\text { centrifuged density }\end{array}$ \\
\hline Residual Analysis & XRD & $\begin{array}{l}\text { Qualitative analysis of any } \\
\text { undigestible residue }\end{array}$ \\
\hline Pyrophoricity & XRD & $\begin{array}{l}\text { Qualitative analysis of the sludge } \\
\text { prior to heating or digestion. } \\
\text { Unreacted metalic uranium and } \\
2 r \text {; unoxidized uranium hydride; } \\
\text { uranium oxide; hydrates of } \mathrm{Al}_{2} \mathrm{O}_{3} \text {, } \\
\mathrm{UO}_{2 \mathrm{x}} \text { and } \mathrm{FeO}_{\mathrm{x}}\end{array}$ \\
\hline $\begin{array}{l}\text { Particle Size } \\
\text { Distribution }\end{array}$ & $\begin{array}{l}\text { Particle size } \\
\text { analyzer }\end{array}$ & Size, distribution \\
\hline Particle Shape & $\begin{array}{l}\text { Optical microscopy, } \\
\text { SEM, or TEM }\end{array}$ & Shape \\
\hline Particle Density & $\begin{array}{l}\text { Gas pycnometer/ } \\
\text { calculation }\end{array}$ & Density dry/density wet \\
\hline Viscosity & Viscometer & Viscosity \\
\hline $\mathrm{TIC} / \mathrm{TOC} / \mathrm{TC}$ & $\begin{array}{l}\text { Persulfate oxidation } \\
\text { and coulometry }\end{array}$ & TIC $\left(\mathrm{CO}_{3}{ }^{2-}\right), \mathrm{TOC}, \mathrm{TC}$ \\
\hline Zeta Potential & Zeta plus instrument & $\mathrm{mV}$ \\
\hline Caustic Demand & $\begin{array}{l}\text { Potentiometric } \\
\text { titration }\end{array}$ & Buffering capacity \\
\hline $\begin{array}{l}\text { Gas Generation from } \\
\text { Shipping Container and } \\
\text { Settlers }\end{array}$ & $\begin{array}{l}\text { Capture measured } \\
\text { volume of gas over } \\
\text { specific time and } \\
\text { analyze for } \\
\text { composition }\end{array}$ & $\begin{array}{l}\text { Rate of gas volume generated (as a } \\
\text { function of hours), composition of } \\
\text { gas released, and temperature of } \\
\text { sludge sample }\end{array}$ \\
\hline pH & pH probe & $\mathrm{pH}$ units \\
\hline Cyanide & Standard methods & Cyanide concentration \\
\hline
\end{tabular}


Table 2. Analytical Requirements for the 105-K West Basin Canister Sludge Samples (222-S and 325 Laboratories).

\begin{tabular}{|c|c|c|c|c|c|}
\hline Process & Constituents & Procedure & Required $\mathrm{MDL}^{1}$ & Precision ${ }^{2}$ & Accuracy \\
\hline \multicolumn{6}{|l|}{ Separation, AEA } \\
\hline & ${ }^{238} \mathrm{Pu}$ & $\begin{array}{l}\text { LA-953-104 } \\
\text { PNL-ALO-455/469 }\end{array}$ & $8.0 \mu \mathrm{Ci} / \mathrm{g}$ & $\pm 25 \%$ & -- \\
\hline & ${ }^{239 / 240} \mathrm{Pu}$ & $\begin{array}{l}\text { LA-953-104 } \\
\text { PNL-AL0-455/469 }\end{array}$ & $3.0 \mu \mathrm{Ci} / \mathrm{g}$ & $\pm 25 \%$ & $\pm 25 \% \mathrm{Sp}$ \\
\hline & ${ }^{2431} \mathrm{Am} / 244 \mathrm{Cm}$ & $\begin{array}{l}\text { LA-953-104 } \\
\text { PNL-ALO-469 }\end{array}$ & $\begin{array}{l}15.0 \mu \mathrm{Ci} / \mathrm{g} \\
15.0 \mu \mathrm{Ci} / \mathrm{g}\end{array}$ & $\pm 25 \%$ & $\begin{array}{l} \pm 25 \% \text { Sp } \\
\text { Am only }\end{array}$ \\
\hline $\begin{array}{l}\text { Phosphorescence } \\
\text { or Fluorimetric }\end{array}$ & U total & $\begin{array}{l}\text { LA-925-009 } \\
\text { PNL-AL0-445 }\end{array}$ & $10 \mu \mathrm{g} / \mathrm{g}$ & $\pm 20 \%$ & SPC \\
\hline $\begin{array}{l}\text { Thermal } \\
\text { Ionization Mass } \\
\text { Spectroscopy } \\
\text { (TIMS) }\end{array}$ & $\begin{array}{l}\text { U I Isotopics }{ }^{233} \mathrm{U},{ }^{234} \mathrm{U},{ }^{235} \mathrm{U},{ }^{236} \mathrm{U}, \\
{ }^{238} \mathrm{U}\left({ }^{236} \mathrm{Pu},{ }^{239}{ }^{26 u}\right. \\
\left.{ }^{240} \mathrm{Pu} \text {, and }{ }^{241} \mathrm{Pu}\right)^{7}\end{array}$ & PNL-ALO-455 & $25 \mu \mathrm{g} / \mathrm{g}$ & $\pm 5 \%$ & SPC \\
\hline \multirow[t]{11}{*}{ GEA } & & $\begin{array}{l}\text { LA-548-121 } \\
\text { PNL-AL0-450/451 }\end{array}$ & & & \\
\hline & ${ }^{134} \mathrm{Cs}$ & & $0.20 \mu \mathrm{Ci} / \mathrm{g}$ & $\pm 25 \%$ & -- \\
\hline & ${ }^{137} \mathrm{Cs}$ & & $0.015 \mu \mathrm{Ci} / \mathrm{g}$ & $\pm 25 \%$ & SPC \\
\hline & ${ }^{60} \mathrm{CO}$ & & $0.010 \mu \mathrm{Ci} / \mathrm{g}$ & $\pm 25 \%$ & SPC \\
\hline & ${ }^{241} \mathrm{Am}$ & & $15.0 \mu \mathrm{Ci} / \mathrm{g}$ & $\pm 25 \%$ & -- \\
\hline & ${ }^{152} \mathrm{Eu}$ & & $1.5 \mu \mathrm{Ci} / \mathrm{g}$ & $\pm 25 \%$ & - \\
\hline & ${ }^{154} \mathrm{Eu}$ & & $1.5 \mu \mathrm{Ci} / \mathrm{g}$ & $\pm 25 \%$ & -- \\
\hline & ${ }^{155} \mathrm{Eu}$ & & $2.0 \mu \mathrm{C} / \mathrm{g}$ & $\pm 25 \%$ & -- \\
\hline & ${ }^{212} \mathrm{Bi}$ & & $10.0 \mu \mathrm{Ci} / \mathrm{g}$ & $\pm 25 \%$ & -- \\
\hline & ${ }^{208} \mathrm{~T} 1$ & & $30.0 \mu \mathrm{Ci} / \mathrm{g}$ & $\pm 25 \%$ & - \\
\hline & ${ }^{125} \mathrm{Sb}$ & & $10.0 \mu \mathrm{Ci} / \mathrm{g}$ & $\pm 25 \%$ & -- \\
\hline
\end{tabular}

'Required Method Detection Limit (MOL) has been established based on expected concentrations and use of the data, taking into account different capabitities of the laboratories for the equipment and analysis methods in use.

2

2 Measured sample precision determined by duplicate snalyses. The Relative Percent Difference (RPD) between the duplicate analyses is within the specified bounds; e.g., $-25 \%<R P D<25 \%$. RPD $=[($ result1 - result2)/mean] $* 100$.

3 All spike recoveries should be within $225 \%$. All method standard recoveries should be within statistical process control (SPC). A serial dilution (SD) will be used to evaluate the method accuracy for some metai analytes.

${ }^{4}$ The sample preparation procedure will provide the calculation used to determine the sludge settled density.

${ }^{5}$ Analyze for PCB using same methods as used for $K$ East canister sludge samples or as directed in LOI. All Aroclor compounds should be ident $i f i$ ed and quant ified.

GIf available from routine analysis, extraordinary measures (purchase of new equipment) not required.

7 Report if data are generated as part of other requested analyses. 
Table 2. Analytical Requirements for the 105-K West Basin Canister Siudge Samples (222-S and 325 Laboratories). (Continued)

\begin{tabular}{|c|c|c|c|c|c|}
\hline Process & Constituents & Procedure & Required $\mathrm{MDL}^{1}$ & Precision ${ }^{2}$ & Accuracy ${ }^{3}$ \\
\hline & ${ }^{106} \mathrm{Ru} / \mathrm{Rh}$ & & $35.0 \mu \mathrm{Ci} / \mathrm{g}$ & $\pm 25 \%$ & -- \\
\hline & ${ }^{144} \mathrm{Ce} / \mathrm{Pr}$ & & $25.0 \mu \mathrm{Ci} / \mathrm{g}$ & $\pm 25 \%$ & -- \\
\hline & ${ }^{95} \mathrm{Nb}$ & & $1.0 \mu \mathrm{Ci} / \mathrm{g}$ & $\pm 25 \%$ & -- \\
\hline & ${ }^{226} \mathrm{Ra}$ & & $45.0 \mu \mathrm{Ci} / \mathrm{g}$ & $\pm 25 \%$ & -- \\
\hline Gross Alpha & Total $\alpha$ & $\begin{array}{l}\text { LA-508-101 } \\
\text { PNL-AL0-461 }\end{array}$ & $3.0 \mu \mathrm{Ci} / \mathrm{g}$ & $\pm 25 \%$ & $\pm 25 \% \mathrm{Sp}$ \\
\hline Gross Beta & Total B & $\begin{array}{l}\text { LA-508-101 } \\
\text { PNL-AL0-463 }\end{array}$ & $0.50 \mu \mathrm{Ci} / \mathrm{g}$ & $\pm 25 \%$ & $\pm 25 \% \mathrm{Sp}$ \\
\hline ICP & Metals & $\begin{array}{l}\text { LA-505-151/161 } \\
\text { PNL-AL0-211 }\end{array}$ & & & \\
\hline & Al & & $100 \mu \mathrm{g} / \mathrm{g}$ & $\pm 25 \%$ & $\pm 10 \%$ SD \\
\hline & Cd & & $15 \mu \mathrm{g} / \mathrm{g}$ & $\pm 25 \%$ & $\pm 25 \% \mathrm{Sp}$ \\
\hline & Sm & & $200 \mu \mathrm{g} / \mathrm{g}$ & $\pm 25 \%$ & $\pm 25 \% \mathrm{Sp}$ \\
\hline & B & & $100 \mu \mathrm{g} / \mathrm{g}$ & $\pm 25 \%$ & $\pm 25 \% \mathrm{Sp}$ \\
\hline & $\mathrm{Fe}$ & & $100 \mu \mathrm{g} / \mathrm{g}$ & $\pm 25 \%$ & $\pm 10 \%$ SD \\
\hline & $\mathrm{Ba}$ & & $100 \mu \mathrm{g} / \mathrm{g}$ & $\pm 25 \%$ & $\pm 25 \% \mathrm{Sp}$ \\
\hline & $\mathrm{Cr}$ & & $20 \mu \mathrm{g} / \mathrm{g}$ & $\pm 25 \%$ & $\pm 25 \% \mathrm{Sp}$ \\
\hline & $\mathrm{Pb}$ & & $200 \mu \mathrm{g} / \mathrm{g}$ & $\pm 25 \%$ & $\pm 25 \% \mathrm{Sp}$ \\
\hline & $\mathrm{Ag}$ & & $20 \mu \mathrm{g} / \mathrm{g}$ & $\pm 25 \%$ & $\pm 25 \% \mathrm{Sp}$ \\
\hline & $\mathrm{Be}$ & & $10 \mu \mathrm{g} / \mathrm{g}$ & $\pm 25 \%$ & $\pm 25 \% \mathrm{Sp}$ \\
\hline & $\mathrm{TI}$ & & $400 \mu \mathrm{g} / \mathrm{g}$ & $\pm 25 \%$ & $\pm 25 \% S p$ \\
\hline & $2 n$ & & $20 \mu \mathrm{g} / \mathrm{g}$ & $\pm 25 \%$ & $\pm 25 \%$ Sp \\
\hline & $\mathrm{Cu}$ & & $20 \mu \mathrm{g} / \mathrm{g}$ & $\pm 25 \%$ & $\pm 25 \% \mathrm{Sp}$ \\
\hline
\end{tabular}

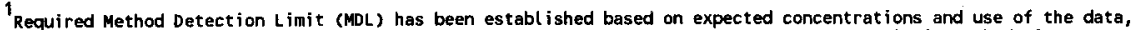
taking into account different capabilities of the laboratories for the equipment and analysis methods in use.

2 Measured sample precision determined by duplicate anatyses. The Relative Percent Difference (RPD) between the duplicate analyses is within the specified bounds; e.g., $-25 \%<\mathrm{RPD}<25 \%$. RPD $=[($ result $1-$ result2)/mean]*100.

3 All spike recoveries should be within $\pm 25 \%$. All method standard recoveries should be within statistical process control (SPC). A serial dilution (SD) will be used to evaluate the method accuracy for some metal analytes.

${ }^{4}$ The sample preparation procedure will provide the calculation used to determine the sludge settled density.

${ }^{5}$ Analyze for PCB using same methods as used for K East canister sludge samples or as directed in LOI. All Aroclor compounds should be identified and quantified.

6If evailable from routine analysis, extraordinary measures (purchase of new equipment) not required.

7 Report if data are generated as part of other requested analyses.

Sp--At least one spike analysis required. 
Table 2. Analytical Requirements for the 105-K West Basin Canister Sludge Samples (222-S and 325 Laboratories). (Continued)

\begin{tabular}{|c|c|c|c|c|c|}
\hline Process & Constituents & Procedure & Required $\mathrm{MDL}^{1}$ & Precision ${ }^{2}$ & Accuracy ${ }^{3}$ \\
\hline & K & & $1000 \mu \mathrm{g} / \mathrm{g}$ & $\pm 25 \%$ & $\pm 25 \% \mathrm{Sp}$ \\
\hline & $\mathrm{Se}$ & & $200 \mu \mathrm{g} / \mathrm{g}$ & $\pm 25 \%$ & $\pm 25 \% \mathrm{Sp}$ \\
\hline & $M n$ & & $20 \mu \mathrm{g} / \mathrm{g}$ & $\pm 25 \%$ & $\pm 25 \% \mathrm{Sp}$ \\
\hline & $\mathrm{Mg}$ & & $200 \mu \mathrm{g} / \mathrm{g}$ & $\pm 25 \%$ & $\pm 25 \% \mathrm{Sp}$ \\
\hline & $\mathrm{Ca}$ & & $200 \mu \mathrm{g} / \mathrm{g}$ & $\pm 25 \%$ & $\pm 25 \% \mathrm{Sp}$ \\
\hline & $\mathrm{Na}$ & & $200 \mu \mathrm{g} / \mathrm{g}$ & $\pm 25 \%$ & $\pm 25 \% \mathrm{Sp}$ \\
\hline & $Z r$ & & $20 \mu \mathrm{g} / \mathrm{g}$ & $\pm 25 \%$ & $\pm 25 \% \mathrm{Sp}$ \\
\hline & $\mathrm{Ni}$ & & $40 \mu \mathrm{g} / \mathrm{g}$ & $\pm 25 \%$ & $\pm 25 \%$ Sp \\
\hline & $P$ & & $400 \mu \mathrm{g} / \mathrm{g}$ & $\pm 25 \%$ & $\pm 25 \%$ Sp \\
\hline & $B i$ & & $200 \mu \mathrm{g} / \mathrm{g}$ & $\pm 25 \%$ & $\pm 25 \% \mathrm{Sp}$ \\
\hline 6 & $\mathrm{Hf}$ & & TBD & $\pm 25 \%$ & $\pm 25 \% \mathrm{Sp}$ \\
\hline 6 & $\overline{S n}$ & & TBD & $\pm 25 \%$ & $\pm 25 \% \mathrm{Sp}$ \\
\hline & U & & $1000 \mu \mathrm{g} / \mathrm{g}$ & $\pm 25 \%$ & $\pm 25 \% \mathrm{Sp}$ \\
\hline IC & $\begin{array}{l}\text { Anions-- } \mathrm{F}^{-}, \mathrm{Cl}^{-}, \mathrm{NO}_{2}^{-}, \\
\mathrm{NO}_{3}^{-}, \mathrm{PO}_{4}{ }^{-2}, \mathrm{SO}_{4}{ }^{2-}, \mathrm{Br}^{2}, \\
\text { oxalate, formate, and } \\
\text { acetate }\end{array}$ & $\begin{array}{l}\text { LA-533-105 } \\
\text { PNL-ALO-212 }\end{array}$ & $20 \mu \mathrm{g} / \mathrm{ml}$ & $\pm 25 \%$ & $\pm 25 \% \mathrm{Sp}$ \\
\hline $\begin{array}{l}\text { Solvent } \\
\text { Extraction with } \\
\text { Liquid } \\
\text { Scintillation } \\
\text { Counter }\end{array}$ & ${ }^{99} \mathrm{Tc}$ & LA-438-101 & $0.05 \mu \mathrm{g} / \mathrm{g}$ & $\pm 25 \%$ & SPC \\
\hline $\begin{array}{l}\text { Exothermic/ } \\
\text { Endothermic }\end{array}$ & $\begin{array}{l}\text { DSC (with air and } \\
\text { nitrogen cover gas) }\end{array}$ & $\begin{array}{l}\text { LA-514-113 } \\
\text { PNL-AL0-508 }\end{array}$ & -- & $\pm 25 \%$ & SPC \\
\hline
\end{tabular}

1 Required Method Detection Limit (MDL) has been established based on expected concentrations and use of the data, taking into account different capabilities of the laboratories for the equipment and analysis methods in use.

2 Measured sample precision determined by duplicate analyses. The Relative Percent Difference (RPD) between the duplicate analyses is within the specified bounds; e.9., $-25 \%<$ RPD $<25 \%$. RPD $=[($ result 1 - result 2 ) $/ m e a n] \star 100$.

3

3 All spike recoveries should be within $\pm 25 \%$. All method standard recoveries should be within statistical process control (SPC). A serial dilution (SD) will be used to evaluate the method accuracy for some metal analytes.

${ }^{4}$ The sample preparation procedure will provide the calculation used to determine the sludge settled density.

5 Analyze for PCB using same methods as used for K East canister sludge samples or as directed in LOl. All Aroclor compounds should be identified and quantified.

6If available from routine analysis, extraordinary measures (purchase of new equipnent) not required.

7 Report if data are generated as part of other requested analyses.

Sp--At least one spike analysis required. 
Table 2. Analytical Requirements for the 105-K West Basin Canister Sludge Samples (222-S and 325 Laboratories). (Continued)

\begin{tabular}{|c|c|c|c|c|c|}
\hline Process & Constituents & Procedure & Required $\mathrm{MDL}^{1}$ & Precision ${ }^{2}$ & Accuracy $^{3}$ \\
\hline $\begin{array}{l}\text { Drained Solids } \\
\text { (TWRS) }\end{array}$ & Percent water (TGA) & $\begin{array}{l}\text { LA-560-112 } \\
\text { PNL-AL0-508 }\end{array}$ & -- & $\pm 25 \%$ & SPC \\
\hline $\begin{array}{l}\text { Drained Solids } \\
\text { (MCOS) }\end{array}$ & Percent water (TGA) & $\begin{array}{l}\text { Specified in } \\
\text { LOI }\end{array}$ & -- & -- & -- \\
\hline $\begin{array}{l}\text { Hot Persulfate/ } \\
\text { Coulometry }\end{array}$ & $\begin{array}{l}\text { TIC }\left(\mathrm{CO}_{3}^{2 *}\right) \text {, and } \\
\text { TOC/TIC/TC }\end{array}$ & $\begin{array}{l}\text { LA-342-100 } \\
\text { PNL-ALO-381 }\end{array}$ & $40 \mu \mathrm{g} / \mathrm{g}$ & $\pm 25 \%$ & $\pm 25 \% \mathrm{Sp}$ \\
\hline $\begin{array}{l}\text { Separation and } \\
\text { Beta Counting }\end{array}$ & ${ }^{90} \mathrm{Sr}$ & $\begin{array}{l}\text { LA-220-101 } \\
\text { PNL-AL0-433 }\end{array}$ & $1.0 \mu \mathrm{Ci} / \mathrm{g}$ & $\pm 25 \%$ & $\pm 25 \% \mathrm{Sp}$ \\
\hline $\begin{array}{l}\text { Extraction and } \\
\text { Alpha Counting }\end{array}$ & ${ }^{237} \mathrm{~Np}$ & $\begin{array}{l}\text { LA-933-141 } \\
\text { PNL-AL0-415/422 }\end{array}$ & $5 \mu \mathrm{Ci} / \mathrm{g}$ & $\pm 25 \%$ & $\pm 25 \%$ Sp \\
\hline Gravimetric & \begin{tabular}{|l|} 
Settled and \\
centrifuged \\
density/volume
\end{tabular} & \begin{tabular}{|l|} 
Sample \\
preparation \\
procedure
\end{tabular} & -- & -- & -- \\
\hline Caustic Demand & Buffering capacity & LA-211-104 & $0.04 \mathrm{~mole} / \mathrm{kg}$ & $\pm 25 \%$ & SPC \\
\hline $\begin{array}{l}\text { XRD--Prior to } \\
\text { Sample Heating } \\
\text { and Acid } \\
\text { Digestion }\end{array}$ & $\begin{array}{l}\text { U (metallic), } \\
\text { Fe hydrates, } \\
\text { Al hydrates, } \\
U \text { hydrides, } U \text { oxides, } \\
\text { and } Z r \text { metal }\end{array}$ & PNL-AL 0-268 & -. & -- & -- \\
\hline $\begin{array}{l}\text { XRD--Digestate } \\
\text { Residue }\end{array}$ & $\begin{array}{l}\text { Any identifiable } \\
\text { compounds (analytes) } \\
\text { after acid digest and } \\
\text { caustic fusion }\end{array}$ & PNL-ALO-268 & -- & -- & -- \\
\hline Settling Rate & $\begin{array}{l}\text { Volume settled versus } \\
\text { time }\end{array}$ & $\begin{array}{l}\text { Sample } \\
\text { preparation } \\
\text { procedure }\end{array}$ & -- & -- & -- \\
\hline
\end{tabular}

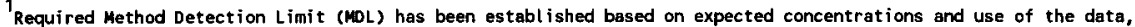
taking into account different capabilities of the laboratories for the equipment and analysis methods in use.

2

2 Measured sample precision determined by duplicate analyses. The Relative Percent Difference (RPD) between the duplicate analyses is within the specified bounds; e.g., $-25 \%<R P D<25 \%$. RPD $=[($ result $1-$ result 2$) /$ mean $] * 100$.

3 All spike recoveries should be within $\$ 25 \%$. All method standerd recoveries should be within statistical process control (SPC). A serial dilution (SD) will be used to evaluate the method accuracy for some metal analytes.

4 The sample preparation procedure will provide the calculation used to determine the sludge settled density.

5 Analyze for PCB using same methods as used for K East canister sludge samples or as directed in LOI. All Aroclor compounds should be identified and quantified.

6 If available from routine analysis, extracrdinary measures (purchase of new equipment) not required.

7 Report if data are generated as part of other requested analyses.

Sp--At least one spike analysis required. 
Table 2. Analytical Requirements for the 105-K West Basin Canister Sludge Samples (222-S and 325 Laboratories). (Continued)

\begin{tabular}{|c|c|c|c|c|c|}
\hline Process & Constituents & Procedure & Required $\mathrm{MDL}^{\top}$ & Precision ${ }^{2}$ & Accuracy $^{3}$ \\
\hline $\begin{array}{l}\text { Particle Size } \\
\text { Analyzer }\end{array}$ & $\begin{array}{l}\text { Particle size } \\
\text { (submicron to } \\
0.25 \text { in.) and } \\
\text { distribution }\end{array}$ & $\begin{array}{l}\text { LT-519-101 } \\
\text { PNL-ALO-530 }\end{array}$ & -- & -- & -- \\
\hline Particle Shape & Shape & PNL-ALO-530 & -- & -- & -- \\
\hline Viscometer & Viscosity & $\begin{array}{l}\text { LT-519-115 } \\
\text { PNL-ALO-502 }\end{array}$ & -- & -- & -- \\
\hline \multirow[t]{2}{*}{ Organics } & SVOA--all TICS & $\begin{array}{l}\text { LA-523-131/406 } \\
\text { PNL-ALO-120/ } \\
344 / 345\end{array}$ & $\begin{array}{l}\text { Report TICs } \\
>10 \mathrm{ppm}\end{array}$ & -- & - \\
\hline & $\begin{array}{l}\text { Polychlorinated } \\
\text { biphenyls (PCB) }\end{array}$ & PNL-AL 0-346 & $\begin{array}{l}1 \mathrm{ppm} \text { (solids) } \\
1 \mathrm{ppb} \text { (water) }\end{array}$ & $\begin{array}{l}-5 \\
--^{5}\end{array}$ & $\begin{array}{l}-5 \\
--5\end{array}$ \\
\hline Zeta Potential & Zeta potential & $\begin{array}{l}\text { TWRS-95-5.6a-2, } \\
\text { Rev. } 0\end{array}$ & TBD & TBD & TBD \\
\hline pH (electrode) & $\mathrm{pH}$ & $\begin{array}{l}\text { LA-212-106 } \\
\text { PNL-ALO-225 }\end{array}$ & $0.1 \mathrm{pH}$ units & $\pm 25 \%$ & SPC \\
\hline $\begin{array}{l}\text { Gas Generation } \\
\text { Rate }\end{array}$ & $\begin{array}{l}\text { Gas volume as rate of } \\
\text { data time (e.g., } \\
\text { hours), volume, and } \\
\text { temperature of sludge } \\
\text { (for shipping } \\
\text { containers and } \\
\text { settling columns) }\end{array}$ & $\begin{array}{l}\text { Test plan } \\
\text { approved by } \\
\text { SNFE group }\end{array}$ & TBD & TBD & TBD \\
\hline Gas Composition & $\begin{array}{l}\mathrm{H}, \mathrm{He}, \mathrm{Ar}, \mathrm{N}_{2}, \mathrm{Xe}, \\
\mathrm{Kr}, \text { tritium, and any } \\
\text { other significant } \\
\text { gases }\end{array}$ & PNL-ALO-284 & TBD & TBD & TBD \\
\hline Cyanide & $\begin{array}{l}\text { LA-695-102 } \\
\text { PNL-AL0-287/289 }\end{array}$ & \begin{tabular}{|l|} 
LA-695-102 \\
PNL-AL0-287/289
\end{tabular} & $5 \mu \mathrm{g} / \mathrm{g}$ & $\pm 25 \%$ & $\pm 25 \%$ \\
\hline
\end{tabular}

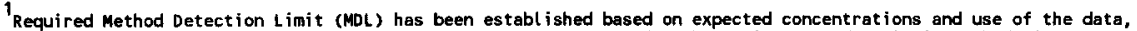
taking into account different capabilities of the laboratories for the equipment and analysis methods in use.

2 Measured sample precision determined by duplicate analyses. The Relative Percent Difference (RPD) between the duplicate analyses is within the specified bounds; e.g., -25\% $<$ RPD $<25 \%$. RPD $=[($ result $1-$ result 2 ) $/$ mean]*100.

3 All spike recoveries should be within $\pm 25 \%$. All method standard recoveries should be within statistical process control (SPC). A serial dilution (SD) will be used to evaluate the method accuracy for some metal analytes.

${ }^{4}$ The sample preparation procedure will provide the calculation used to determine the sludge settled density.

5 Analyze for PCB using same methods as used for $K$ East canister sludge samples or as directed in LO1. All Aroclor compounds should be identified and quantified.

6 If avaitable from routine analysis, extraordinary measures (purchase of new equipment) not required.

7 Report if data are generated as part of other requested analyses.

sp--At least one spike analysis required. 
the specified requirements as noted in Table 2. If the precision between duplicates or the spike recoveries exceed the appropriate criteria there are two options; (1) make one rerun to see if acceptable results are obtained (if acceptable results are not obtained, report the QC failure to SNFE group) or (2) report QC failure and suggested actions immediately to SNFE group Program Coordinator for evaluation.

The method detection level (MDL) as used in this document is the detection level which is expected to be achievable by the laboratory to analyze a listed constituent, yet is low enough to detect whether the constituent is present in concentrations significant to resolving data quality objectives (Makenas 1996a).

Precision and accuracy requirements for laboratory analytical results specified in this document are based on an assessment of achievable laboratory capabilities, given the complex nature of the samples to be analyzed, their radioactive nature; and the consequent handling, dilution, and analysis methods prescribed. The precision and accuracy statements calculated from the recent $K$ East Basin sludge samples were also considered in determining the requirements presented in Table 2. The DQOS for this sampling effort (Makenas 1996a) consolidate and incorporate the various analyses performed to assure that the overall process will produce the analytical results leading to a realization of the sampling objectives. 
HNF-SD-SNF-PLN-020, Rev. 0

This page intentionally left blank. 


\subsection{LABORATORY REPORTING REQUIREMENTS}

The laboratories will be required to submit a final report within a period defined in the LOI from SNFE group Project Coordinator to the laboratories. Opportunities for parallel operations will be developed and schedules will be prepared for laboratory work which will minimize the time actually required. Samples will be processed through the laboratory with the priority required to meet the completion date given in the LOI. The laboratory will be required to submit interim preliminary data reports to the SNFE group Project Coordinators as requested. The final reports submitted to the DESH SNFE group Project Coordinators for technical review will conform to the requirements for a "full" data package (e.g., similar to Silvers 1995; Miller 1996). The data package will give the duplicate results, all the QC data (laboratory method control standard results, spike recovery results, hot cell blank results, the equipment blank results), deviations from any of the requirements, chain of custody forms, and a narrative. Additional information on the data report content is given in Sections 3.1 and 3.2.

Data related to dose rates measured on samples to be shipped between the 325 and 222-S analytical laboratories, should be transmitted from the shipping laboratory to the receiving laboratory at least 5 working days prior to the actual shipment.

The laboratory performing the analyses of the PCB concentrations in the sludge samples will inform the SNFE group Project Coordinator as soon as definitive data are available and provide a summary. This information will be transmitted by the SNFE group Project Coordinator to the other involved laboratories for their use, in case there are any impacts on managing waste from these sample analyses. The information will also be provided to K. L. Pearce, SNF/TWRS Project Coordinator.

\subsection{DATA PACKAgING}

Analytical analysis results will be reviewed and processed on a priority basis by the analytical laboratories and other supporting organizations to meet the schedules provided in the LOI. 
HNF-SD-SNF-PLN-020, Rev. 0

This page intentionally left blank. 


\subsection{FINAL SUMMARY REPORT REQUIREMENTS}

The completed data packages from the analytical laboratories will be sent to the SNFE group Project Coordinator who will coordinate data review and final summary data report preparation. The data will be reviewed specifically against the criteria set in the DQO document, Makenas 1996a. The Project Coordinator will ensure the data and reports become a part of the permanent facility records per CM-3-5, Document Control and Records Management Manual. Content of the laboratory data report is further discussed in Sections 3.2 and 4.0.

\subsection{STATISTICAL ANALYSIS REQUIREMENTS}

A statistical analysis of the data will be performed as a separate activity from the overall laboratory final data package. This analysis will be reported as part of the final summary report to be completed by the SNFE group. For each analyte, analys is of variance (ANOVA) techniques will be used to fit a statistical model to the data. This statistical model can be used to:

- Estimate the variability between samples (heterogeneity of the canisters sampled)

- Estimate the analytical variability (precision)

- Compute a $95 \%$ confidence interval on the mean concentration for each analyte

- Compare $K$ West Basin canister sludge data to K East Basin floor sludge data and $K$ East Basin canister sludge data. 
HNF-SD-SNF-PLN-020, Rev. 0

This page intentionally left blank. 
HNF-SD-SNF-PLN-020, Rev. 0

\subsection{SAFETY PLANS}

\subsection{RADIATION/INDUSTRIAL SAFETY}

An industrial safety assessment will be performed prior to the start of these activities consistent with the requirements of each performing facility or laboratory. The requirements of HSRCM-1, Hanford Site Radiological Control Manual, shall be adhered to during the performance of sampling activities.

\subsection{NUCLEAR CRITICALITY SAFETY}

A Criticality Safety Assessment will be performed in accordance with requirements of each facility or laboratory involved [e.g., K Basin Master Work Plan (MWP-95-005)], prior to the start of each activity. The requirements determined by these assessments shall be adhered to during the performance of the sampling activities. 
HNF-SD-SNF-PLN-020, Rev . 0

This page intentionally left blank. 


\subsection{ALARA PLAN}

The sampling procedure for the activities discussed in Section 2.3.1 will take into consideration exposure reduction techniques which will minimize the radiation exposure to the sampling team.

ALARA considerations will be an integrated part of the design effort for the sampling and sampling equipment to minimize personnel exposure. The following exposure reduction techniques or their equivalent will be used during the sampling process (also see Baker 1996c):

a. Approved procedures will be used which take into account the anticipated radiation exposure rate levels.

b. Personnel will be trained on the procedures prior to using them.

c. Personnel training will include cold facility training through the procedures.

d. Shielding and/or remote operation of the equipment will be used where possible.

e. Time required to collect samples will be minimized through thorough analysis of each sampling activity.

f. A contingency procedure will be provided for use when sampling problems arise.

g. As required Health Physics staff will conduct a pre-job meeting with the sampling team, and the SNFE group Test Engineer will conduct a daily briefing with the sampling team on the planned activities for that day.

h. Hand exposure during sample transfers will be monitored using finger ring TLDs, if required.

i. Members of the sampling team, including observers, will be limited to only those absolutely necessary to properly perform the sampling activities.

j. Health Physics personnel will establish dose rate "standby areas" for the sampling team members.

As a result of the above ALARA actions, estimates of the overall total whole-body exposure to the sampling team personnel and Radiation Technician will be projected and closely monitored. 
HNF-SD-SNF-PLN-020, Rev. 0

This page intentionally left blank. 


\subsection{QUALITY ASSURANCE AND CONTROL PLAN}

All sampling, sample handling, sample packaging/shipping, and analytical process activities will be performed in accordance with the requirements of this plan, along with the approved sampling and analysis procedures. The controls identified in this plan, along with those contained in the program plan, have been established to assure the applicable quality assurance requirements of CM-4-2, Qual ity Assurance Manual, are satisfied during the performance of this activity. In addition, the analytical laboratory will perform the analyses to its internal quality assurance program plans. The 222-S Laboratory will follow WHC-SD-CP-QAPP-016, Quality Assurance Program Plan for Laboratory Analysis and Process Testing. The 325 Laboratory will follow MCS-033, Quality Assurance Plan for Activities Conducted by the Analytical Chemistry Laboratory.

Method specific quality control and quality assurance such as calibrations and blanks are found in the analytical procedures noted in Table 2. Sample quality control (duplicates, spikes, and standards) are identified in Section 3.2 or in the following paragraph. If no criteria are provided in the current document, the performing laboratory shall perform to its quality assurance plan(s).

Sample groups will be assigned categories in LOI that reflect the number of duplicates and spike analyses that should be run. The categories are:

\section{Category

Laboratories will select four of the samples, from the seven "normal" samples, for duplicate analyses and one sample for spike analyses. The balance of the samples will be handled as normal laboratory batches with $Q A$ as per the first paragraph of this section.

2 For the two "research" samples the laboratories will run duplicates on layer analyses, no spike analyses are required.

As noted previously, duplicates are repeats of all analyses after completion of settling analyses. Selection of samples within categories should optimize the use of samples with larger volumes for duplicates, a) lowing the maximum number of requested analyses to be performed for each category.

Care should be taken with water samples processed in conjunction with the sludge analyses (e.g., equipment blanks, etc.), processing them on a best effort basis with criteria similar to that called out in Table 2, the applicable laboratory procedures, or as called for in the final LOI. 
HNF-SD-SNF-PLN-020, Rev. 0

This page intentionally left blank. 


\subsection{REFERENCES}

Alderman, C. J., 1997, Internal Memo to R. P. Omberg, "Request for Additional Laboratory Tests on Archive K East Basin Floor/Pit Sludge and Canister Sludge," CJA-97-001.

Baker, R. B., 1996a, System Design Description for Sampling in K Basin Fuel Storage Canisters, WHC-SD-SNF-SDD-004, Rev. 0, Westinghouse Hanford Company, Richland, Washington.

Baker, R. B., 1996b, Internal Memo to R. P. Omberg, "Recommended K West Bas in Canisters for Sludge Sampling, "Westinghouse Hanford Company, Richland, Washington.

Baker, R. B., 1995a, Sampling Apparatus System Design Description: Sampling Equipment for $K$ Basin Floor Sludge, WHC-SD-SNF-SDD-003, Rev. 0 , Westinghouse Hanford Company, Richland, Washington.

Baker, R. B., 1995b, Summary Status of K Basin Sludge Characterization, WHC-SD-SNF-TI-006, Rev. 0, Westinghouse Hanford Company, Richland, Washington.

Baker, R. B., 1995c, Internal Memo to T. L. Welsh, Potential Parameters Influencing Floor Sludge Volume or Composition at K East Basin, (Appendix in Welsh 1995), Westinghouse Hanford Company, Richland, Washington.

Bechtold, D. B., 1994, Report of Laboratory Test Plan for Analysis of K East Basin Backwash Pit Samples, WHC-SD-NR-TRP-021, Rev. 0, Westinghouse Hanford Company, Richland, Washington.

Bechtold, D. B., 1993, Laboratory Test Plan for Analysis of K East Basin Backwash Pit Samples, WHC-SD-NR-TP-023, Rev. 0, West inghouse Hanford Company, Richland, Washington.

Bridges, A. E., 1996, Internal Memo to D. L. Edwards and K. J. Young, Instructions for Cleaning K Basin Canister Sludge Sample Containers, Westinghouse Hanford Company, Richland, Washington.

Fowler, K. D., 1995a, Data Quality Objectives for the Waste Compatibility Program, WHC-SD-WM-DQ0-001, Rev. 1, Westinghouse Hanford Company, Richland, Washington.

Fowler, K. D., 1995b, Tank Farm Waste Compatibility Program, WHC-SD-WM-OCO-015, Rev. OA, Westinghouse Hanford Company, Richland, Washington.

HSRCM-1, Hanford Site Radiological Control Manual, Westinghouse, Hanford Company, Richland, Washington.

Makenas, B. J., Pearce, K. L., and Baker, R. B., 1996a, Data Quality Objectives for $K$ West Basin Canister Sludge Sampling, WHC-SD-SNF-DQ0-012, Rev. 0, Westinghouse Hanford Company, Richland, Washington. 


\subsection{REFERENCES (Continued)}

Makenas, B. J., 1996b, Canister Choices for Sampling of Fuel and Sludge from $K$ West Basin Canisters, HNF-SD-SNF-SM-006, Rev. O, Duke Engineering and Services Hanford, Inc., Richland, Washington.

Makenas, B. J., et al., 1996c, Analysis of S7udge from the $K$ East Basin and Wease7 Pit, WHC-SP-1182, Westinghouse Hanford Company, Richland, Washington.

Meznarich, H. K., 1995, Quality Assurance Program Plan for Laboratory Analysis and Process Testing, WHC-SD-CP-QAPP-016, Rev. 0, Westinghouse Hanford Company, Richland, Washington .

Miller, G. L., 1997, Chemical and Radiochemical Characterization of Tank 105-K Basin Canister S7udge, HNF-SD-WM-DP-228, Rev. 0, Rust Federal Services of Hanford, Inc., Richland, Washington.

Miller, G. L., 1996, Final Chemical and Radiochemical Analytical Report for 105-K East Floor S7udge, WHC-SD-SNF-DP-004, Rev. 1C, Westinghouse Hanford Company, Richl and, Washington.

Miller, G. L., 1995, Interim Chemical and Radiochemical Analytical Report of 105-K East Basin S7udge, WHC-SD-SNF-DP-004, Rev. 0, Westinghouse Hanford Company, Richland, Washington.

Pitner, A. L., 1997, Visual Examinations of $K$ West Fuel Elements, HNF-SD-SNF-TI-046, Rev. 0, Duke Engineering and Services Hanford, Inc., Richland, Washington.

Pitner, A. L., 1996, Test Plan for K East Visual and Ultrasound Survey of Candidate Canisters for Fue7 and S7udge Characterization, WHC-SD-SNF-TP-024, Rev. 0, Westinghouse Hanford Company, Richland, Washington.

PNL, 1991, Quality Assurance Plan for Activities Conducted by the Analytical Chemistry Laboratory (ACL), MCS-033, Rev. 0, Pacific Northwest Laboratories, Richland, Washington.

Silvers, K. L., 1997, K East Basin Canister S7udge Sample Analysis, Pacific Northwest National Laboratory, Richland, Washington.

Silvers, K. L., 1995, K Basin Sludge Sample Analysis, Basin Floor and Weasel Pit, Pacific Northwest National Laboratory, Richland, Washington.

Trimble, D. J., and T. L. Welsh, 1997a, Cesium-137 in K West Basin Canister Water, HNF-SD-SNF-ANAL-014, Rev. 0, Duke Engineering and Services Hanford, Inc., Richland, Washington.

Trimble, D. J., Internal Memo to D. S. Takasumi, 1997b, "K West Basin Canister Sludge Inventory." 


\subsection{REFERENCES (Continued)}

Welsh, T. L., R. B. Baker, B. J. Makenas, and K. L. Pearce, 1996, Sampling and Analysis Plan for Sludge Located in Fuel Storage Canisters of the 105-K East Basin, WHC-SD-SNF-PLN-016, Rev. 0, Duke Engineering and Services Hanford, Inc., Richland, Washington.

Welsh, T. L., R. B. Baker, B. J. Makenas, and K. L. Pearce, 1995, Sampling and Analysis Plan for Floor Sludge of the 105-K East Main Basin and Weasel Pit, WHC-SD-SNF-PLN-006, Rev. 0, Westinghouse Hanford Company, Richland, Washington.

CM-2-14, Hazardous Material Packaging and Shipping, Fluor Daniel Hanford, Inc., Richl and, Washington.

CM-3-5, Document Control and Records Management Manual, Fluor Daniel Hanford, Inc., Richland, Washington.

CM-4-2, Quality Assurance Manua7, Fluor Daniel Hanford, Inc., Richland, Washington.

CM-5-4, Laboratories Administration, Fluor Daniel Hanford, Inc., Richland, Washington.

Williams, N. H., Letter to E. D. Sellers (RL), 1996, "Sludge Disposal Plan of Execution," 9656039.

Willis, N. P., 1993, Hanford Site Waste Acceptance Criteria, WHC-EP-0063-4, Westinghouse Hanford Company, Richland, Washington. 


\begin{tabular}{|c|c|c|c|c|c|}
\hline \multicolumn{6}{|c|}{ DISTRIBUTION SHEET } \\
\hline To & \multirow{2}{*}{\multicolumn{3}{|c|}{$\begin{array}{l}\text { From } \\
\text { Spent Nuclear Fuel Evaluations } \\
\text { 2T650 }\end{array}$}} & \multicolumn{2}{|l|}{ Page 1 of 2} \\
\hline Distribution & & & & \multicolumn{2}{|c|}{ Date $04 / 21 / 97$} \\
\hline \multicolumn{4}{|l|}{ Project Title/Work Order } & \multicolumn{2}{|c|}{ EDT No. 620779} \\
\hline Spent Nuclear Fuel Pro & D-SNF-PLN-020, & Rev. 0 & & \multicolumn{2}{|l|}{ ECN No. } \\
\hline Name & MSIN & $\begin{array}{l}\text { Text } \\
\text { With All } \\
\text { Attach. }\end{array}$ & Text Or & $\begin{array}{l}\text { Attach./ } \\
\text { Appendix } \\
\text { Only }\end{array}$ & $\begin{array}{c}\text { EDT/ECN } \\
\text { Only }\end{array}$ \\
\hline
\end{tabular}

U.S. Department of Energy.

Richland Operations Office

K. K. Kawabata

J. Shuen

S7-55 $X$

P. G. Loscoe

S7-41

S7-41

$\hat{x}$

Fluor Daniel Hanford. Inc.

E. W. Gerber

R3-11

$x$

B\&W Protec, Inc.

T. L. Welsh

T4-40

$x$

Duke Engineering \& Services Northwest. Inc.

M. J. Horhota B1-13

$x$

Pacific Northwest Laboratory

P. R. Bredt

G. R. Golcar

A. B. Johnson

G. L. Ketner

S. C. Marschman

A. J. Schmidt

K. L. Silvers

J. M. Tingey
P7-25 $\quad X$

P7-20 $X$

K8-34 $X$

$\mathrm{K} 5 \mathrm{-22} \quad \mathrm{X}$

P7-27 $\quad X$

K3-75 $\quad x$

$\mathrm{K} 9-08 \quad \mathrm{X}$

P7-25 $\quad x$

Duke Engineering \& Services, Hanford Inc.

C. J. Alderman

R. B. Baker (5)

D. W. Bergmann

K. H. Bergsman

L. D. Bruggeman

A. E. Bridges

S. A. Chastain

C. Defigh-Price

R. G. Gant

M. A. Green

J. J. Jernberg

C. D. Kirk
R3-48

HO-40

R3-86

R3-48

HO- 40

HO-40

HO- 40

$\times 3-79$

$\times 3-79$

$\times 3-56$

$\times 3-72$

R3-85 


\section{DISTRIBUTION SHEET}

\begin{tabular}{|c|c|c|c|c|c|}
\hline \multirow{2}{*}{$\begin{array}{l}\text { To } \\
\text { Distribution }\end{array}$} & \multirow{2}{*}{\multicolumn{3}{|c|}{$\begin{array}{l}\text { From } \\
\text { Spent Nuclear Fuel Evaluations } \\
2 T 650\end{array}$}} & \multicolumn{2}{|l|}{ Page 2 of 2} \\
\hline & & & & \multicolumn{2}{|c|}{ Date $04 / 21 / 97$} \\
\hline \multicolumn{4}{|l|}{ Project Title/Work Order } & \multicolumn{2}{|c|}{ EDT No. 620779} \\
\hline Spent Nuclear Fuel Pro. & D-SNF-PLN-020, & Rev. 0 & & \multicolumn{2}{|l|}{ ECN No. } \\
\hline Name & MSIN & $\begin{array}{l}\text { Text } \\
\text { With All } \\
\text { Attach. }\end{array}$ & Text Only & $\begin{array}{l}\text { Attach./ } \\
\text { Appendix } \\
\text { Only }\end{array}$ & $\begin{array}{l}\text { EDT/ECN } \\
\text { Only }\end{array}$ \\
\hline
\end{tabular}

Duke Engineering \& Services, Hanford Inc. (Continued)
R. E. Lacey
L. A. Lawrence
P. G. LeRoy
C. D. Lucas
P. J. MacFarlan
B. J. Makenas
(5)
F. W. Moore
R3-15
HO- 40
R3-15
$\times 3-67$
$\mathrm{HO}-40$
HO- 40
$\times 3-85$
R. P. Omberg
HO-40
T. R. Pauly
K. L. Pearce (2)
X3-85
R3-48
$\times 3-71$
D. W. Siddoway
D. W. Smith
J. A. Swenson
D. J. Trimble
D. J. Watson
Central Files
R3-15
R3-11
$\mathrm{HO}-40$
X3-79
A3-88
R3-11

$$
\begin{aligned}
& X \\
& X \\
& X \\
& X \\
& X \\
& X \\
& X \\
& X \\
& X
\end{aligned}
$$
SNF Project Files

Lockheed Martin Hanford Corp.

T. M. Blaak

K. G. Carothers

K. D. Fowler

B. A. Higley

C. H. Mulkey

Numatec Hanford Corporation

C. R. Miska

Rust Federal Services of Hanford. Inc.
G. B. Griffin
S. M. Joyce
G. L. Miller
C. T. Narquis

$\begin{array}{ll}\text { S5-13 } & X \\ \text { R1-56 } & X \\ \text { R2-11 } & X \\ \text { H5-27 } & X \\ \text { R1-51 } & X\end{array}$

R3-86 X

$\begin{array}{ll}\text { T6-12 } & X \\ \text { T6-04 } & X \\ \text { T6-06 } & X \\ \text { T6-16 } & X\end{array}$

